\title{
Geohydrology and Ground-Water Quality in the Vicinity of a Ground- Water-Contamination Site in Rockford, Illinois
}

By ROBERT T. KAY, SCOTT T. PRINOS, and FREDERICK L. PAILLET

Prepared in cooperation with the

U.S. ENVIRONMENTAL PROTECTION AGENCY

U.S. GEOLOGICAL SURVEY

Water-Resources Investigations Report 93-4187 


\title{
U.S. DEPARTMENT OF THE INTERIOR BRUCE BABBITT, Secretary
}

\author{
U.S. GEOLOGICAL SURVEY \\ GORDON P. EATON, Director
}

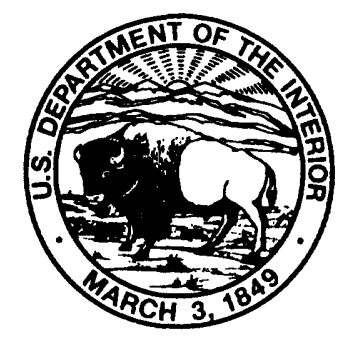

Any use of trade, product, or firm names in this publication is for descriptive purposes

only and does not imply endorsement by the U.S. Government.

For additional information, write to:

District Chief

U.S. Geological Survey

102 E. Main Street, 4th Floor

Urbana, IL 61801
Copies of this report can be purchased from:

U.S. Geological Survey

Earth Science Information Center

Open-File Reports Section

Box 25286, MS 517

Denver Federal Center

Denver, CO 80225 


\section{CONTENTS}

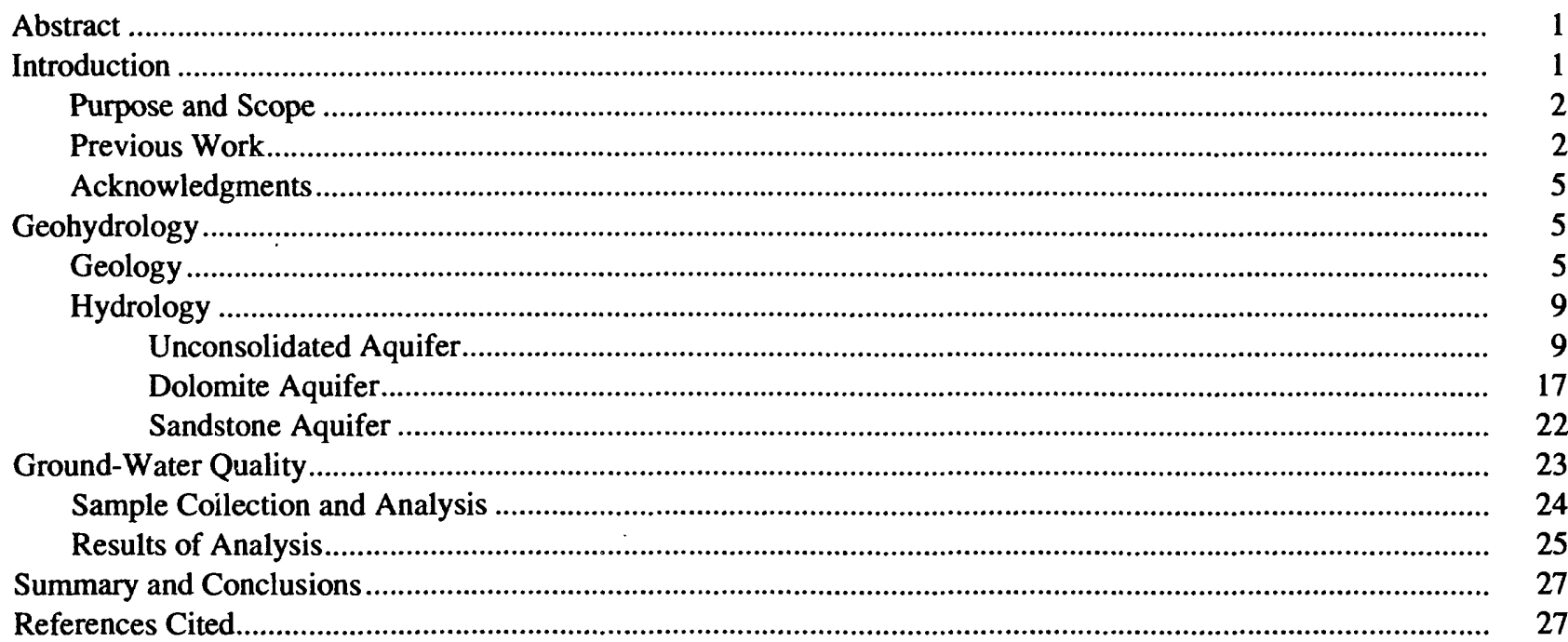

\section{FIGURES}

1-4. Maps showing:

1. Location of Southeast Rockford Ground-Water Contamination Site, Phase I area, and study area

2. Location of boreholes, municipal-supply well, and lines of geologic section in the vicinity of the Southeast Rockford Ground-Water Contamination Site

3. Concentration of trichloroethane in ground water from the unconsolidated aquifer in the vicinity of the Southeast Rockford Ground-Water Contamination Site, October 1991

4. Concentration of trichloroethane in ground water from the dolomite aquifer in the vicinity of the Southeast Rockford Ground-Water Contamination Site, October 1991

5-10. Diagrams showing:

5. Generalized geohydrologic column showing the stratigraphy and geohydrologic units in the Rockford, Ill., area

6. Natural-gamma, acoustic-televiewer, and flowmeter data, and total concentration of volatile organic compounds in the packed intervals for borehole $\mathrm{BH} 1$ in the vicinity of the Southeast Rockford Ground-Water Contamination Site.

7. Natural-gamma, acoustic-televiewer, and flowmeter data, and total concentration of volatile organic compounds in the packed intervals for borehole $\mathrm{BH} 2$ in the vicinity of the Southeast Rockford Ground-Water Contamination Site...

8. Natural-gamma, acoustic-televiewer, and flowmeter data, and total concentration of volatile organic compounds in the packed intervals for borehole BH3 in the vicinity of the Southeast Rockford Ground-Water Contamination Site.

9. Correlation of natural-gamma data along line of section A-A' in the vicinity of the Southeast Rockford Ground-Water Contamination Site.

10. Correlation of acoustic-televiewer data along line of section A-A' in the vicinity of the Southeast Rockford Ground-Water Contamination Site.

11-13. Maps showing:

11. Bedrock topography in the vicinity of the Southeast Rockford Ground-Water Contamination Site

12. Water-table altitude in the vicinity of the Southeast Rockford Ground-Water Contamination Site, October 1991 


\section{CONTENTS}

\section{FIGURES}

\section{1-13. Maps showing:--Continued}

13. Water-level altitude in the dolomite aquifer in the vicinity of the Southeast Rockford Ground-Water Contamination Site, October 1991

14. Schematic diagram of the packer assembly and ground-water-sampling pump in a borehole...

15. Diagram showing correlation of flowmeter data along line of section $A-A^{\prime}$ in the vicinity of the Southeast Rockford Ground-Water Contamination Site

16. Graph showing water level in borehole $\mathrm{BH} 3$ and total daily pumpage from Rockford municipal well 16, Rockford, Ill., December 5-21, 1992

TABLES

1. Borehole and monitoring-well data, Southeast Rockford Ground-Water Contamination Site

2. Depth to water above, within, and below the test interval under approximately hydrostatic conditions during packer testing in boreholes BH1 and BH2, Southeast Rockford Ground-Water Contamination Site

3. Volume of water purged from test intervals before sample collection in boreholes $\mathrm{BH} 1, \mathrm{BH} 2$, and $\mathrm{BH} 3$, Southeast Rockford Ground-Water Contamination Site

4. Results of water-quality sampling from test intervals in boreholes $\mathrm{BH} 1, \mathrm{BH} 2$, and $\mathrm{BH} 3$, Southeast Rockford Ground-Water Contamination Site

\section{CONVERSION FACTORS, VERTICAL DATUM, AND ABBREVIATED WATER-QUALITY UNITS}

\begin{tabular}{rll}
\hline Multiply & By & To obtain \\
\hline foot $(\mathrm{ft})$ & 0.3048 & meter \\
mile $(\mathrm{mi})$ & 1.609 & kilometer \\
acre & 4,047 & square meter \\
gallon $(\mathrm{gal})$ & 3.785 & liter \\
gallon per minute $(\mathrm{gal} / \mathrm{min})$ & 0.06309 & liter per second \\
foot per foot $(\mathrm{ft} / \mathrm{ft})$ & 0.3048 & meter per meter \\
foot per day $(\mathrm{ft} / \mathrm{d})^{1}$ & 0.3048 & meter per day \\
foot squared per day $(\mathrm{ft} / \mathrm{d})^{2}$ & 0.09290 & meter squared per day \\
\hline
\end{tabular}

Sea level: In this report, "sea level" refers to the National Geodetic Vertical Datum of 1929 (NGVD of 1929)-a geodetic datum derived from a general adjustment of first-order level nets of both the United States and Canada, formerly called Sea Level Datum of 1929.

Abbreviated water-quality units used in this report: Chemical concentration is given in micrograms per liter $(\mu \mathrm{g} / \mathrm{L})$. Micrograms per liter is a unit expressing the concentration of chemical constituents in solution as weight (milligrams) of solute per unit volume (liter) of water. One thousand micrograms per liter is equivalent to one milligram per liter.

${ }^{1}$ Foot per day is the mathematically reduced term of cubic foot per day per square foot of aquifer cross-sectional area.

${ }^{2}$ Foot squared per day is the mathematically reduced term of cubic foot per day per square foot times foot of aquifer thickness $\left.\left[\left(\mathrm{ft}^{3} / \mathrm{d}\right) / \mathrm{ft}^{2}\right) \mathrm{ft}\right]$. 


\title{
Geohydrology and Ground-Water Quality in the Vicinity of a Ground-Water-Contamination Site in Rockford, Illinois
}

\author{
By Robert T. Kay, Scott T. Prinos, and Frederick L. Paillet
}

\section{Abstract}

A geohydrologic investigation was performed by the U.S. Geological Survey, in cooperation with the U.S. Environmental Protection Agency, to determine the distribution of volatile organic compounds in a fractured-rock aquifer near the Southeast Rockford Ground-Water Contamination Site in Rockford, Ill. The geologic units of concern are the St. Peter Sandstone and Glenwood Formations; the dolomites of the Platteville and Galena Groups; and the sands, gravels, silts, and clays of Quaternary age. The hydraulic units of concern are the unconsolidated aquifer, composed of sand and gravel; the dolomite aquifer, composed of the Galena and Platteville Groups and the dolomitic parts of the Glenwood Formation; and the sandstone aquifer, composed of the St. Peter Sandstone and the sandstone deposits in the Glenwood Formation. The dolomite aquifer is hydraulically connected to the unconsolidated aquifer and the sandstone aquifer.

Caliper and acoustic-televiewer data show several subhorizontal fractures in the dolomite that can be correlated throughout the study area. Comparison of televiewer and flowmeter data indicates that most of the flow in the dolomite aquifer is through these fractures. Ground-water flow through two of the fractures can be correlated over large parts of the study area.

Volatile organic compounds, in concentrations exceeding 2,000 micrograms per liter, were detected within the entire thickness of the dolomite aquifer where flow is measurable. Volatile organic compounds were detected in an area of the aquifer where they were thought to be absent in previous investigations.

\section{INTRODUCTION}

A geohydrologic investigation was performed in the fall of 1992 to determine the hydraulic properties and distribution of volatile organic compounds (VOC's) in three boreholes that penetrate the uppermost bedrock aquifer near the Southeast Rockford Ground-Water Contamination Site in Rockford, Ill. (figs. 1, 2; table 1). This information was required to (1) guide future geohydrologic investigations in this area, (2) assess ground-water remediation scenarios, and (3) provide some preliminary indication of whether VOC's in the ground water pose a threat to the Rockford municipal water supply. The investigation was conducted by the U.S. Geological Survey (USGS) as part of an Interagency Agreement with the U.S. Environmental Protection Agency (USEPA).

The investigation was divided into two components: geophysical logging and water-quality sampling. Geophysical logging was done to characterize the stratigraphy, to determine the location and orientation of fractures in the dolomite bedrock, and to identify the location and direction of groundwater flow within the dolomite aquifer. Waterquality sampling was done to identify the type, concentration, and distribution of VOC's within the dolomite aquifer.

The Southeast Rockford Ground-Water Contamination Site is bounded by Harrison Avenue to the north, Sawyer Road to the south, 8th Street to the west, and 22nd Street to the east (fig. 1). Recent studies by Camp Dresser \& McKee Inc. (1992) have focused on a much larger area, hereafter referred to as the "Phase I area", which is bounded by Wendy Lane to the east, Sandy Hollow Road to the south, the Rock River to the west, and Harrison Avenue to the north (fig. 1). This report focuses on that part of 


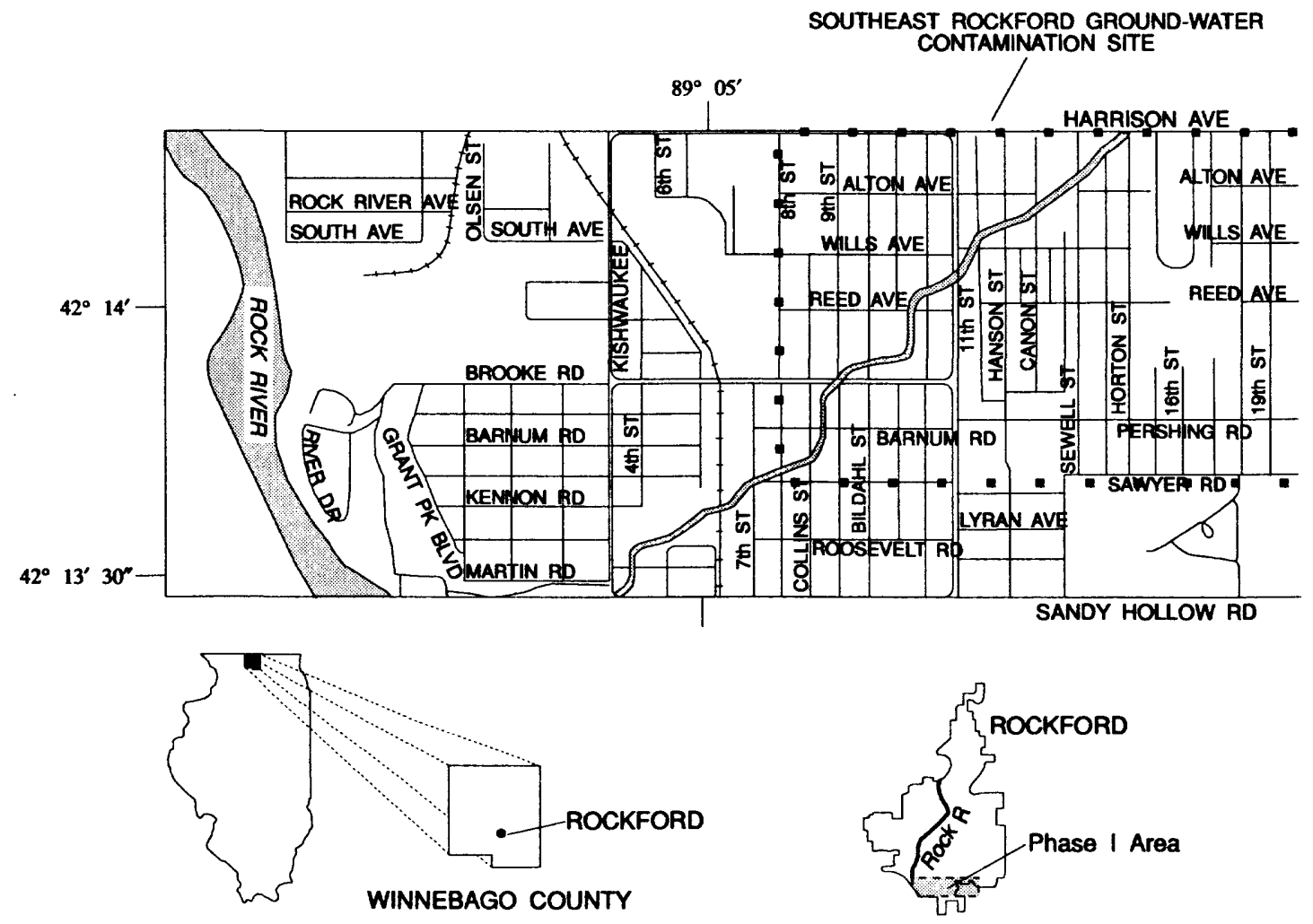

Figure 1. Location of Southeast Rockford Ground-Water Contamination Site, Phase I area, and study area.

the Phase I area between Alpine Road, Sandy Hollow Road, 20th Street, and Harrison Avenue. This area is hereafter referred to as the "study area" (fig. 1).

\section{Purpose and Scope}

This report describes the results of an investigation designed to characterize the geohydrology and distribution of VOC's in the dolomite aquifer beneath the study area. In addition to a description of the geology and hydrology in the Phase I area, results of geophysical logging and water-quality sampling from three boreholes in the study area are presented. The report identifies the concentration and distribution of VOC's in the fractured bedrock aquifer and identifies a number of processes that affect the type and distribution of the VOC's. The report evaluates the potential for contamination of the municipal water-supply aquifers that underlie the uppermost bedrock aquifer.

\section{Previous Work}

In response to concerns about area-wide ground-water-quality degradation brought on by VOC detections in several water-supply wells, Wehrman and others (1988) characterized ground-water quality throughout the greater Rockford area. Though the investigators concluded that regional contamination of ground water was not present in the Rockford area, VOC's were detected in the unconsolidated aquifer in much of southeast Rockford. Wehrman and others (1988) recommended that additional investigations focus on the southeast Rockford area to determine the sources, nature, and extent of contamination.

The first geohydrologic investigation to focus on a specific part of southeast Rockford was conducted at a facility located in the northeastern part of the Phase I area (EDI Engineering and Science, 1989). Ground-water-quality data obtained during this investigation documented the presence of VOC's, especially 1,1,1-trichloroethane, in the unconsolidated aquifer 


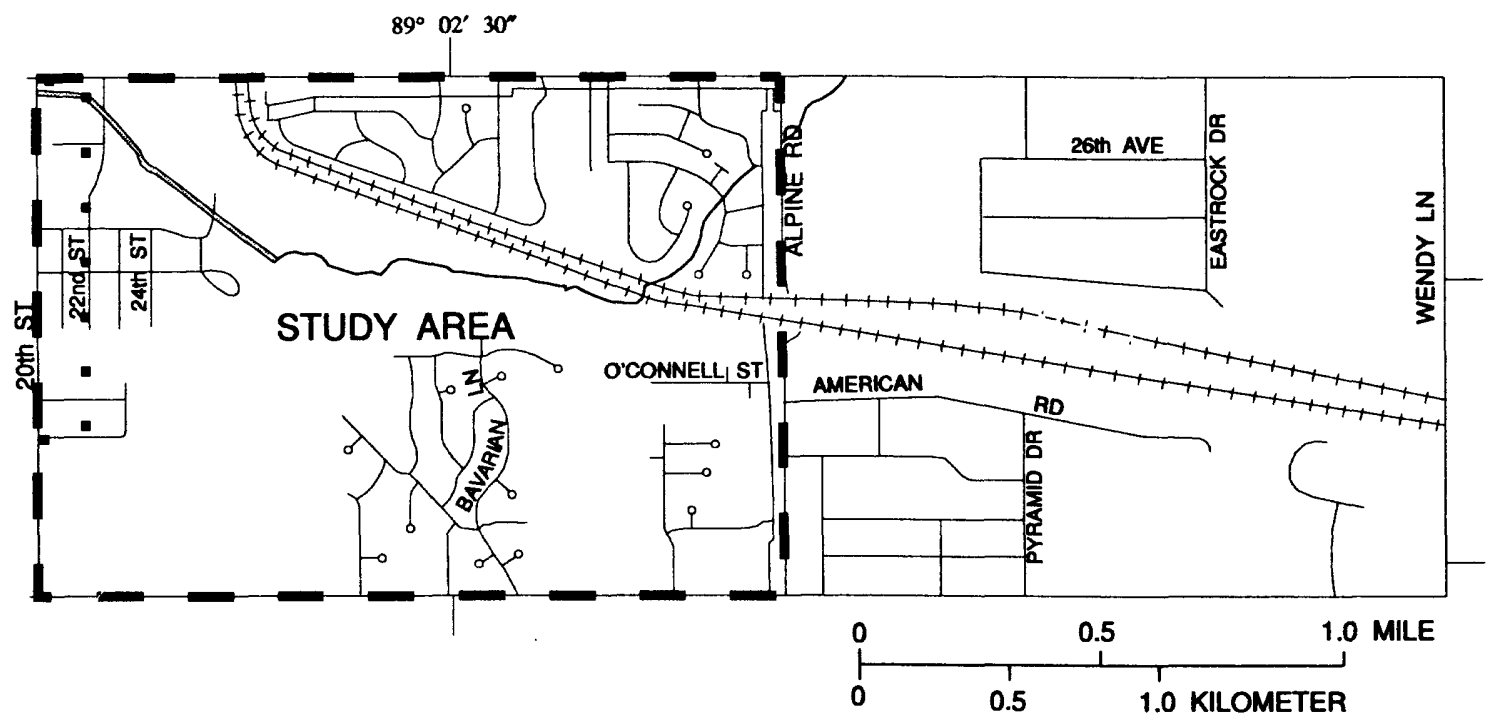

Figure 1. Continued.

Table 1. Borehole and monitoring-well data, Southeast Rockford Ground-Water Contamination Site

[Locations shown in fig. 2. Depth and open interval in feet below measurement point; casing diameter is inside diameter, in inches; measurement-point altitude is in feet above sea level]

\begin{tabular}{ccccc}
\hline Name & Depth & $\begin{array}{c}\text { Open } \\
\text { interval }\end{array}$ & $\begin{array}{c}\text { Casing } \\
\text { diameter }\end{array}$ & $\begin{array}{c}\text { Measurement- } \\
\text { point } \\
\text { altitude }\end{array}$ \\
\hline Borehole: & & & & \\
BH1 & 220.6 & $139.0-220.6$ & 6 & 790.86 \\
BH2 & 254.2 & $48.3-254.2$ & 8 & 765.05 \\
BH3 & 250.0 & $177.0-250.5$ & 6 & 1810 \\
& & & & \\
$\begin{array}{c}\text { Well completed } \\
\text { in borehole: }\end{array}$ & & & & \\
BH1 & 213.0 & $200.0-215.0$ & 2 & 790.33 \\
BH2 & 202.0 & $192.0-204.0$ & 2 & 764.93 \\
BH3 & Abandoned & & & \\
\hline
\end{tabular}

\footnotetext{
'Estimated from topographic map.
} 


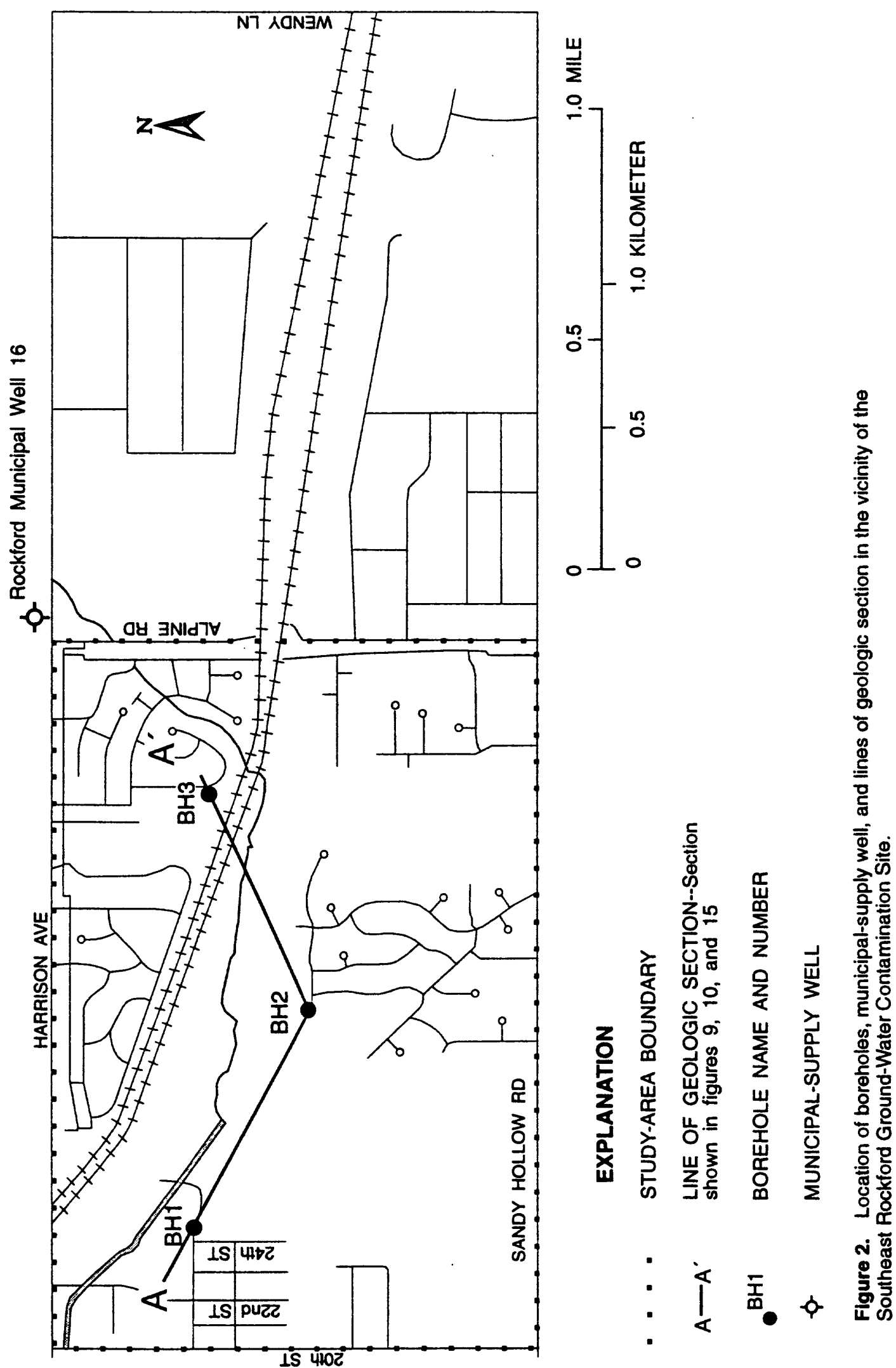


and in the upper part of the underlying dolomite aquifer beneath this facility. The investigators concluded that a narrow plume of VOC's was migrating near the top of the bedrock beneath the facility. Three purge wells open to the dolomite aquifer are currently (1993) in operation at the facility, removing ground water that is treated and disposed of outside of the study area.

Camp Dresser \& McKee Inc. (1990) compiled ground-water-quality data collected by the Illinois Department of Public Health, Illinois Environmental Protection Agency (IEPA), and the USEPA in southeast Rockford. Water samples also were collected by Camp Dresser \& McKee Inc. from more than 100 residential-supply wells within the Phase I area. This sampling revealed an extensive plume of VOC's in the unconsolidated aquifer trending west-northwest through the approximate center of the Phase I area. Most of the residences where water contained VOC's have since been connected to the city of Rockford municipal water supply.

Camp Dresser \& McKee Inc. (1992) conducted the first phase of a Remedial Investigation and Feasibility Study (RIFS) in the Phase I area from June through October 1991. Ground-water-quality data collected during the RIFS identified two VOC plumes composed primarily of trichloroethane: The first plume is located north of the railroad tracks; the second plume is located south of the tracks. Each of these plumes extends from the unconsolidated aquifer into the upper part of the dolomite aquifer (figs. 3,4). The maximum depth of the VOC's in ground water was not defined during the RIFS.

\section{Acknowledgments}

The authors wish to extend their appreciation to Karen Vendl, Project Manager, U.S. Environmental Protection Agency, and Paul Takacs, Project Manager, Illinois Environmental Protection Agency, for their active support and participation during this project. The authors also appreciate the assistance of Wallace Parson, City of Rockford, for his assistance throughout the investigation.

\section{GEOHYDROLOGY}

The geohydrology of the unconsolidated deposits and the upper part of the bedrock was studied in some detail during previous investigations. This investigation was designed to focus on the geohydrology of the deeper parts of the bedrock deposits.

\section{Geology}

This geologic description of the study area is based on the geologic descriptions contained in previous reports (Wehrman and others, 1988; EDI Engineering and Science, 1989; Camp Dresser \& McKee Inc., 1992), observation of outcrops in the Rockford area, and analysis of lithologic and geophysical logs compiled during this and prior investigations. The stratigraphic nomenclature used in this report is that of the Illinois State Geological Survey (Willman and others, 1975, p. 61-80 and 218-230) and does not necessarily follow the usage of the USGS.

The bedrock geologic units of concern to this investigation consist of sandstones and dolomites of Ordovician age. From oldest to youngest, these units are the St. Peter Sandstone and Glenwood Formations, and the Platteville and Galena Groups. Bedrock deposits are unconformably overlain by glacial and fluvioglacial deposits of Quaternary age (fig. 5).

The St. Peter Sandstone is a coarse- to mediumgrained quartz arenite. The sandstone is well rounded, well sorted, and poorly cemented. Lithologic logs of Rockford municipal well 16 indicate that the St. Peter Sandstone is about $320 \mathrm{ft}$ thick in the study area.

The Glenwood Formation consists of interbedded dolomitic shale, sandy argillaceous dolomite, and coarse-grained quartz sandstones. Lithologic and geophysical logs from wells approximately $10 \mathrm{mi}$ south of the study area indicate that the Glenwood Formation is approximately $40 \mathrm{ft}$ thick (Harding-Lawson Associates, 1990, Appendix B). The dolomitic shale and argillaceous dolomite deposits are distinguished from the overlying deposits by their softness and higher clay content.

The Platteville and Galena Groups consist of fractured, partly cherty, partly argillaceous dolomite. The two groups are subdivided into formations on the basis of subtle variations in clay and silt content (Willman and Kolata, 1978, p. 7). Shale partings are common throughout the deposits, and bentonite beds have been identified at some locations. The combined thickness of the Platteville and Galena Groups within the study area ranges from about $150 \mathrm{ft}$ at 


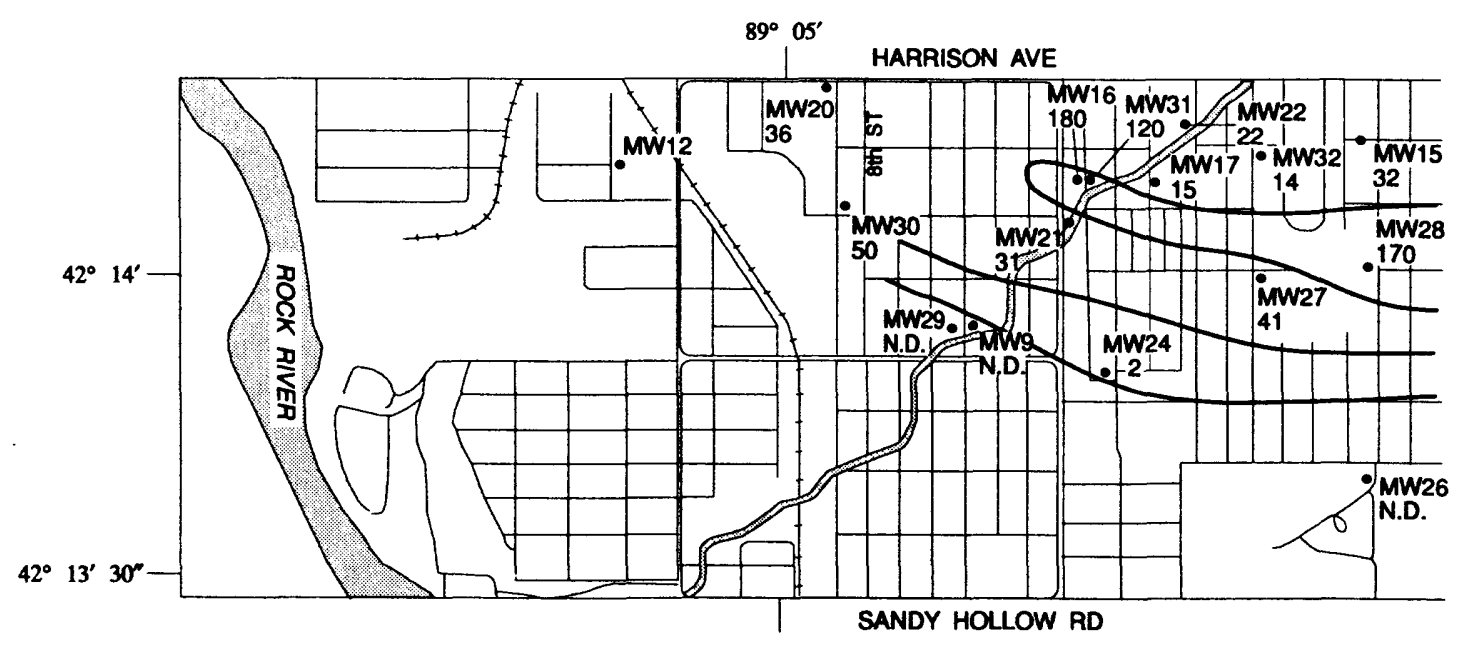

EXPLANATION

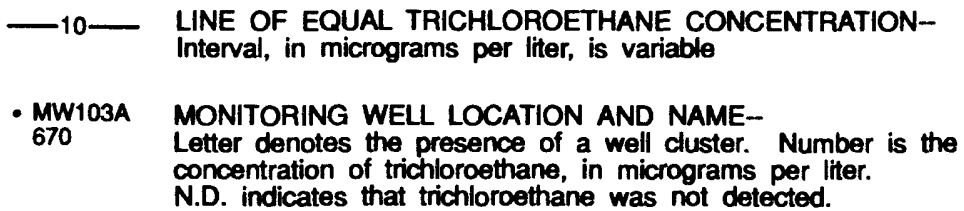

Figure 3. Concentration of trichloroethane in ground water from the unconsolidated aquifer in the vicinity of the Southeast Rockford Ground-Water Contamination Site, October 1991 (modified from Camp Dresser \& McKee Inc., 1992, fig. 4-9).

borehole BH1 to about $360 \mathrm{ft}$ near Rockford municipal well 16 (fig. 2).

Natural-gamma logs were run in boreholes $\mathrm{BH} 1$, $\mathrm{BH} 2$, and $\mathrm{BH} 3$ to enable correlation of the deposits composing the Glenwood Formation and the Platteville and Galena Groups throughout the study area

(figs. 6-9). The correlation demonstrates that the beds are nearly horizontal, perhaps slightly dipping to the east (fig. 9). The natural-gamma data also indicate that boreholes $\mathrm{BH} 1$ and $\mathrm{BH} 2$ penetrate the top of the Glenwood Formation. The top of the Glenwood Formation is estimated to be about $15 \mathrm{ft}$ below the bottom of borehole $\mathrm{BH}$.

A survey of fracture orientations in the dolomite, taken in several quarries in the Rockford area, indicates that the two primary directions of strike of the vertical fractures in the dolomite range from N. $60 \mathrm{~W}$. to N. 80 W. and from N. 20 E. to N. 30 E. (Foote, 1982, p. 23 and 27). Horizontal fracturing also is present in the dolomite.

In an effort to determine the location and orientation of fractures and solution openings in the bedrock, acoustic-televiewer logs were run in boreholes $\mathrm{BH} 1$, $\mathrm{BH} 2$, and BH3 (figs. 6-8). Acoustic-televiewer data show several large subhorizontal fractures in the dolomite at each of the boreholes. Numerous smaller subhorizontal fractures and vuggy zones also were detected.

Comparison of acoustic-televiewer and naturalgamma data reveals that subhorizontal fractures are present in argillaceous and nonargillaceous parts of the dolomite. Comparison of acoustic-televiewer and natural-gamma data also reveals that many of the peaks on the natural-gamma logs are associated with fractures (figs. 6-8).

Correlation of the acoustic-televiewer data demonstrates that the fractures dip toward the east and can be correlated throughout the study area (fig. 10). The orientation of the fractures mirrors the orientation of the beds in the dolomite deposits. This suggests that there is some lithologic and stratigraphic control on the location of horizontal fractures in the study area. This finding is consistent with the results of an analysis of core samples collected at a Superfund site about 


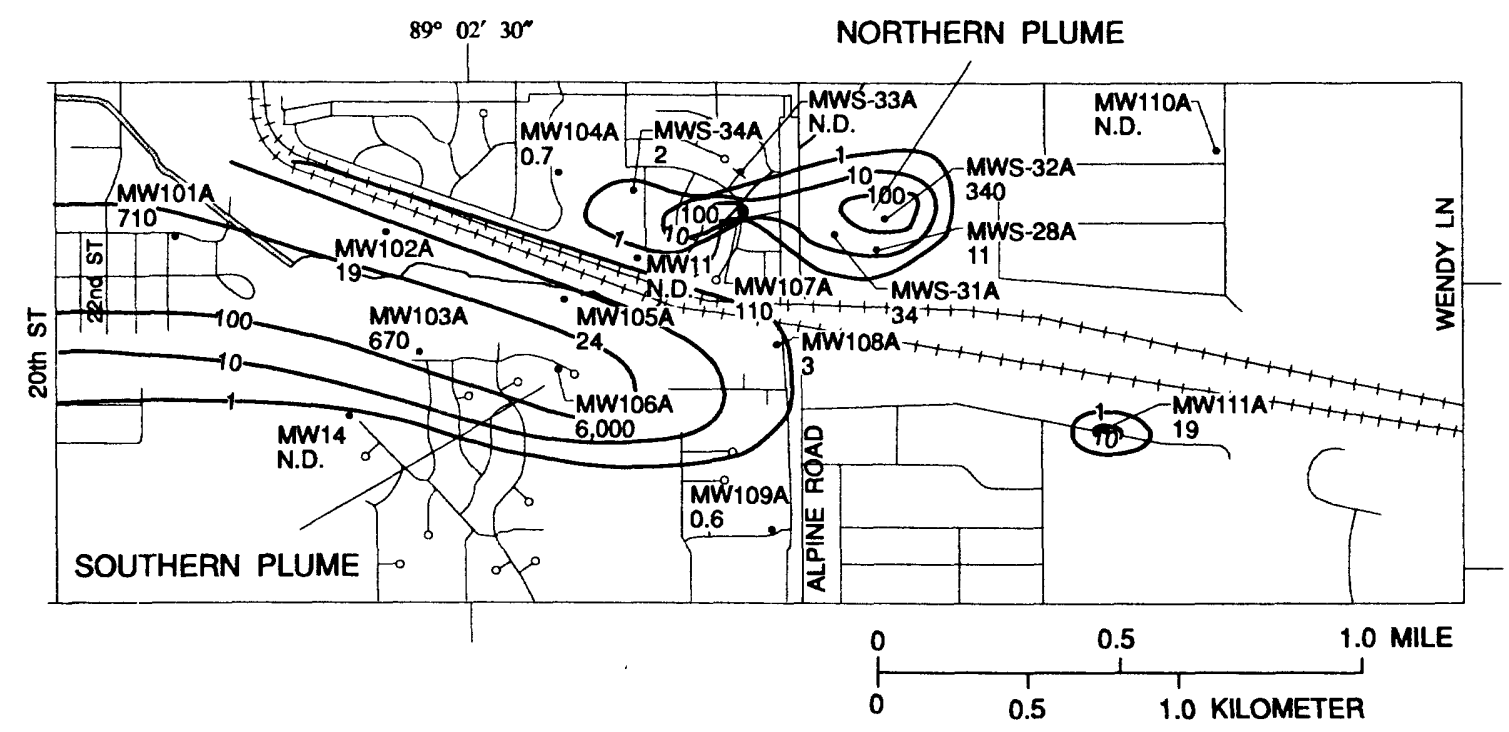

Figure 3. Continued.

$10 \mathrm{mi}$ east of the study area; in these core samples, investigators noted a tendency for fracturing to be concentrated along stratigraphic horizons (Michael Sargent, Illinois State Geological Survey, written commun., 1992).

Comparison of acoustic-televiewer and naturalgamma data shows that vugs tend to be concentrated in the nonargillaceous parts of the dolomite. This is because the processes responsible for the formation of vugs are inhibited by the presence of clay minerals during and after deposition. It is probable, therefore, that the nonargillaceous formations in the Platteville and Galena Groups (Grand Detour, Nachusa, upper Dunleith, Wise Lake, and Dubuque) will be vuggier than the argillaceous formations (Pecatonica, Mifflin, Quimby's Mill, Specht's Ferry, Guttenburg, and lower Dunleith) (Dennis Kolata, Illinois State Geological Survey, oral commun., 1992). Fractures, joints, and solution openings may be preferentially located in the nonargillaceous parts of the dolomite because vuggy zones are relatively susceptible to chemical dissolution and structural deformation. It should be noted, however, that the televiewer data from these three boreholes do not indicate that fracture size or fracture density in the vuggy zones is noticeably greater than fracture size or fracture density in the nonvuggy zones. The observed correlation between fracture location and clay peaks indicates that lithologic and stratigraphic factors other than vug formation are influencing fracture development.

The configuration of the bedrock surface reveals an east-west trending bedrock valley beneath the center of the Phase I area (fig. 11). This valley deepens to the west where it merges with the Rock Bedrock Valley, an ancient precursor to the modern Rock River Valley. The Galena, Platteville, and Glenwood deposits have been removed by erosion beneath the Rock Bedrock Valley. The unconsolidated deposits directly overlie the St. Peter Sandstone near the Rock Bedrock Valley.

Quaternary deposits in the study area consist of silt and clay interbedded with sand and gravel. Individual silt and clay beds do not appear to be continuous for more than a few hundred feet and cannot be correlated throughout the study area. Analysis of the lithologic logs reveals that thick (greater than $35 \mathrm{ft}$ ) silt and clay deposits directly overlie the bedrock at boreholes BH1 and BH3 and at well MW102C (figs. 2, 4). Coarse-grained deposits overlie the bedrock in the remainder of the study area. West of the study area, the Quaternary deposits become thicker and coarser grained as the dolomite deposits become thinner. This trend reflects the increased effect of glaciofluvial erosion and deposition with increasing proximity to the Rock River and the ancestral Rock Bedrock Valley. 


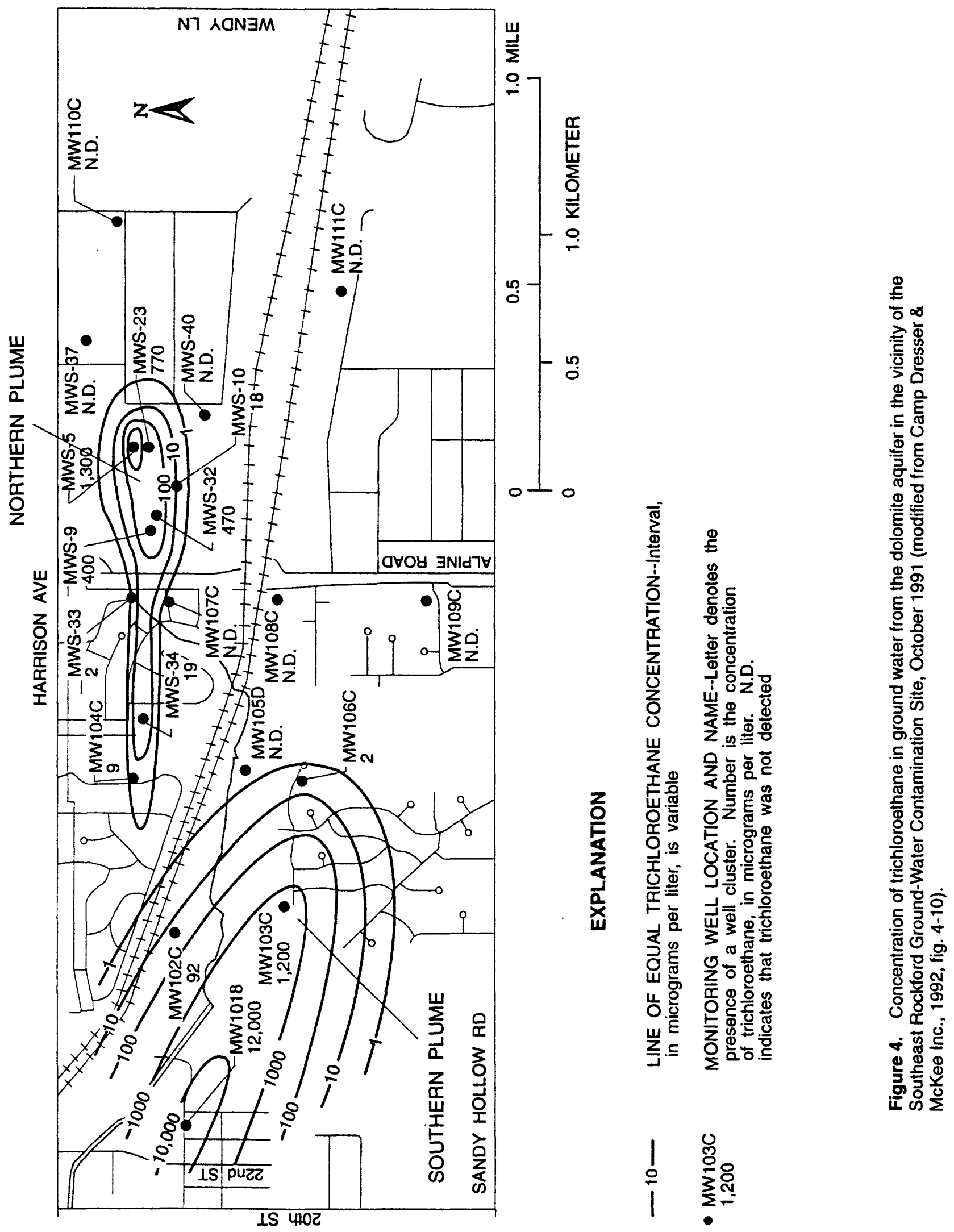




\begin{tabular}{|c|c|c|c|c|}
\hline SYSTEM & GROUP & FORMATION & LITHOLOGY & $\underset{\text { UNIT }}{\text { GEOHYDROLOGIC }}$ \\
\hline QUATERNARY & & & $\begin{array}{l}\text { Silt and Clay, } \\
\text { Sand and } \\
\text { Gravel }\end{array}$ & $\begin{array}{c}\text { Unconsolidated } \\
\text { Aquifer }\end{array}$ \\
\hline \multirow{12}{*}{ ORDOVICIAN } & \multirow{5}{*}{ GALENA } & Dubuque & \multirow{10}{*}{ Dolomite } & \multirow{10}{*}{ Dolomite Aquifer } \\
\hline & & Wise Lake & & \\
\hline & & Dunleith & & \\
\hline & & Guttenburg & & \\
\hline & & Specht's Ferry & & \\
\hline & \multirow{5}{*}{ PLATTEVILLE } & Mimbu & & \\
\hline & & Nachusa & & \\
\hline & & Grand Detour & & \\
\hline & & Mifflin & & \\
\hline & & Pecatonica & & \\
\hline & \multirow{2}{*}{ ANCELL } & Glenwood & $\begin{array}{l}\text { Dolomitic Shale, } \\
\text { Sandstone }\end{array}$ & \multirow{2}{*}{ Sandstone Aquifer } \\
\hline & & St. Peter Sandstone & Sandstone & \\
\hline
\end{tabular}

Figure 5. Generalized geohydrologic column showing the stratigraphy and geohydrologic units in the Rockford, III., area (modified from Willman and others, 1975, fig. 0-4).

\section{Hydrology}

The geologic units in the study area can be divided into three aquifers: the unconsolidated aquifer, the dolomite aquifer, and the sandstone aquifer (fig. 5). The unconsolidated aquifer is composed of saturated sand and gravel deposits. The dolomite aquifer is composed of the Platteville and Galena dolomites and the dolomites in the Glenwood Formation. The sandstone aquifer is composed of the St. Peter Sandstone and the sandstone beds in the Glenwood Formation.

\section{Unconsolidated Aquifer}

The unconsolidated aquifer is a water-table aquifer. The saturated thickness of this aquifer within the study area generally is greatest in the center of the bedrock valley and thinnest on the flanks of the valley. A localized semiconfining unit is present at the base of the aquifer near boreholes $\mathrm{BH} 1$ and $\mathrm{BH} 2$ and at the
MW102 well cluster (figs. 2, 3). The unconsolidated aquifer is pumped for municipal water supply west of the study area.

The mean horizontal hydraulic conductivity of the unconsolidated aquifer calculated from slug-test data collected from five monitoring wells open to the aquifer in the Phase I area east of 20th Street was $2.4 \times 10^{0} \mathrm{ft} / \mathrm{d}$ (Camp Dresser \& McKee Inc., 1992, p. 3-17). The horizontal hydraulic conductivity of the aquifer west of 20th Street is assumed to be significantly higher than it is east of 20th Street because of the thick sequences of relatively coarse-grained deposits in this area.

Water-level data indicate that water in the unconsolidated aquifer flows from southeast to northwest in the Phase I area (fig. 12). Some of this water eventually discharges into the Rock River (Wehrman and others, 1988, p. 37).

Vertical hydraulic gradients between the unconsolidated aquifer and the underlying dolomite aquifer range from $1.1 \times 10^{-3} \mathrm{ft} / \mathrm{ft}$ to $8.4 \times 10^{-2} \mathrm{ft} / \mathrm{ft}$ and 


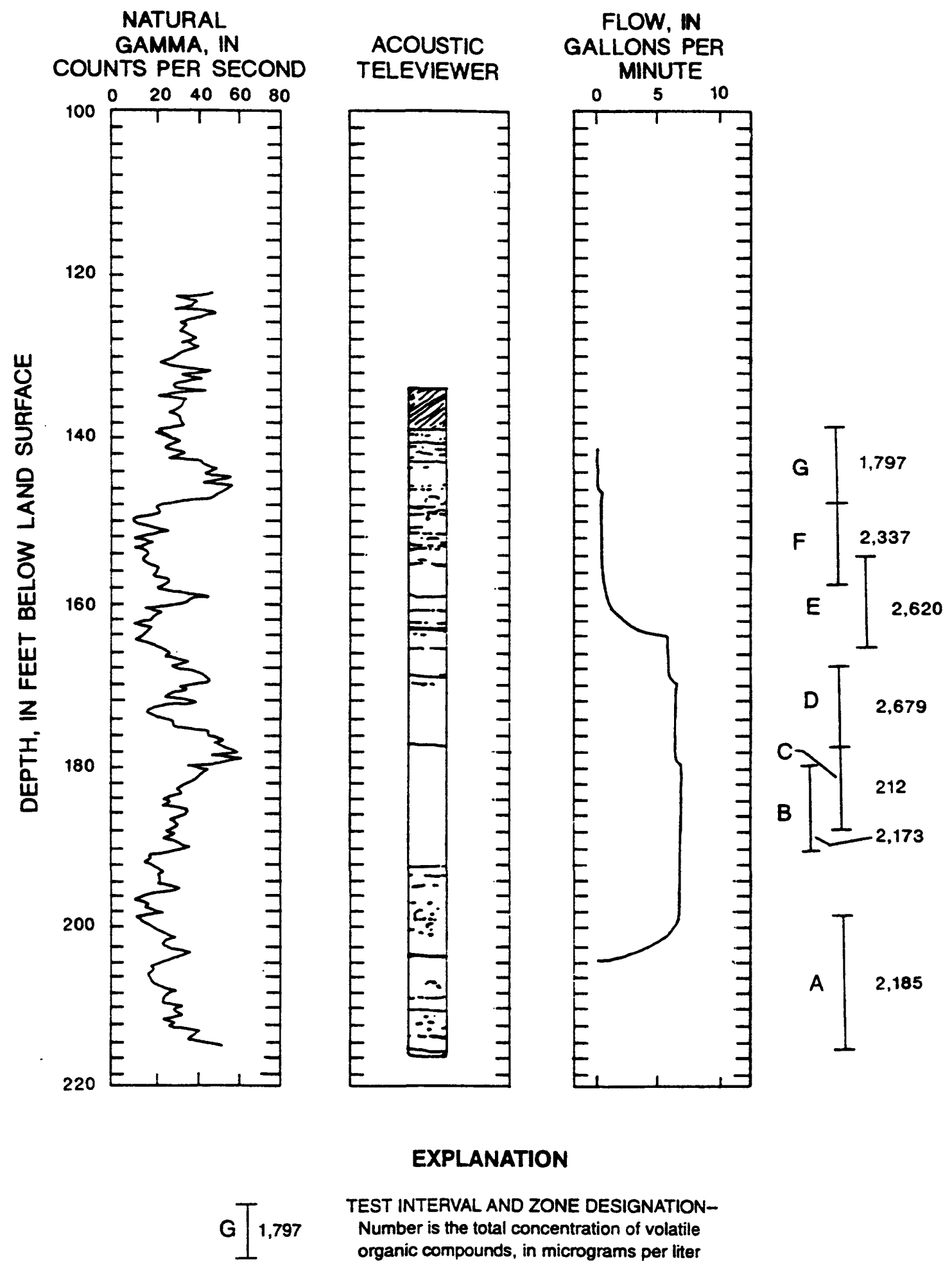

Figure 6. Natural-gamma, acoustic-televiewer, and flowmeter data, and total concentration of volatile organic compounds in the packed intervals for borehole $\mathrm{BH} 1$ in the vicinity of the Southeast Rockford Ground-Water Contamination Site. 


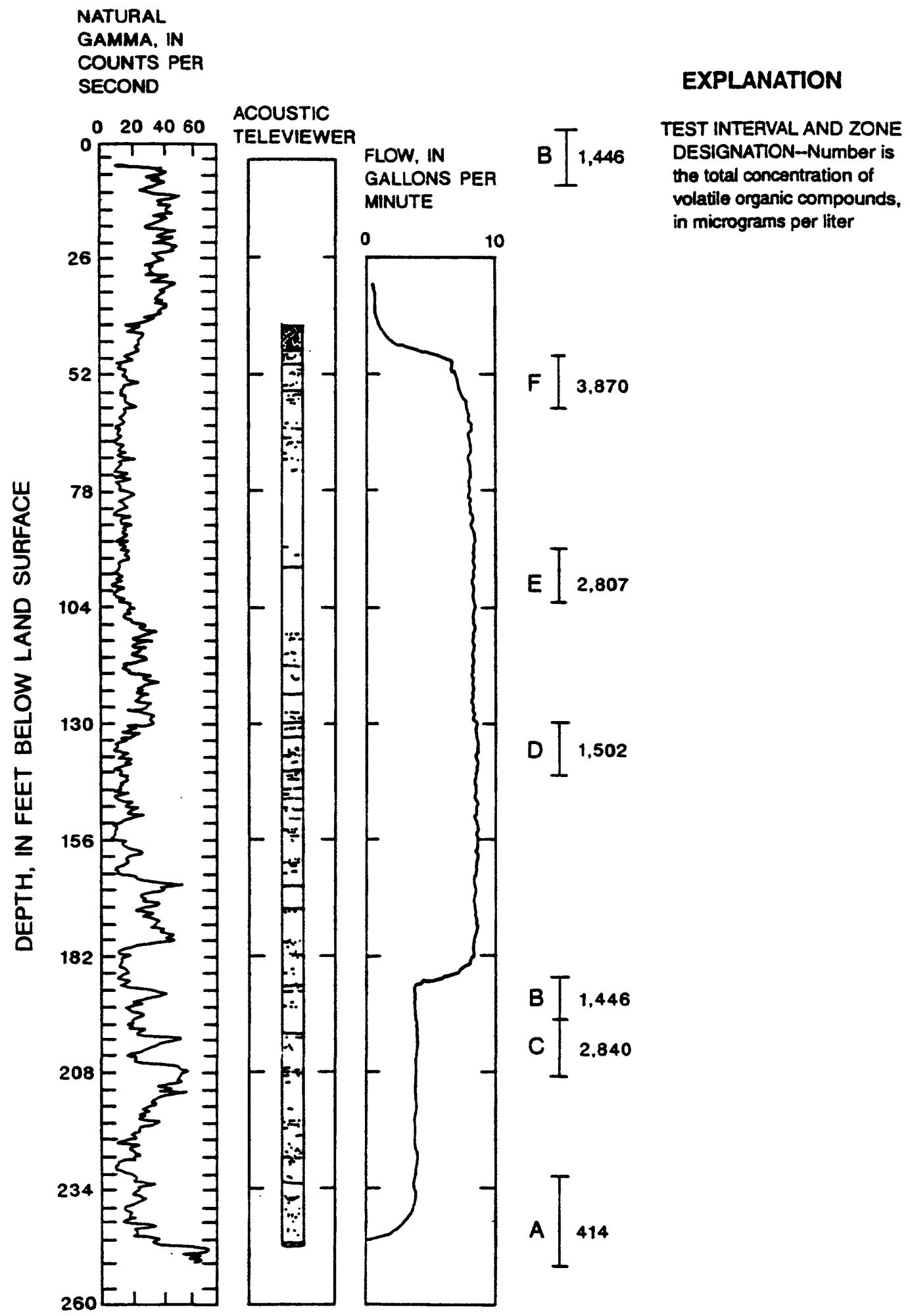

Figure 7. Natural-gamma, acoustic-televiewer, and flowmeter data, and total concentration of volatile organic compounds in the packed intervals for borehole $\mathrm{BH} 2$ in the vicinity of the Southeast Rockford Ground-Water Contamination Site. 


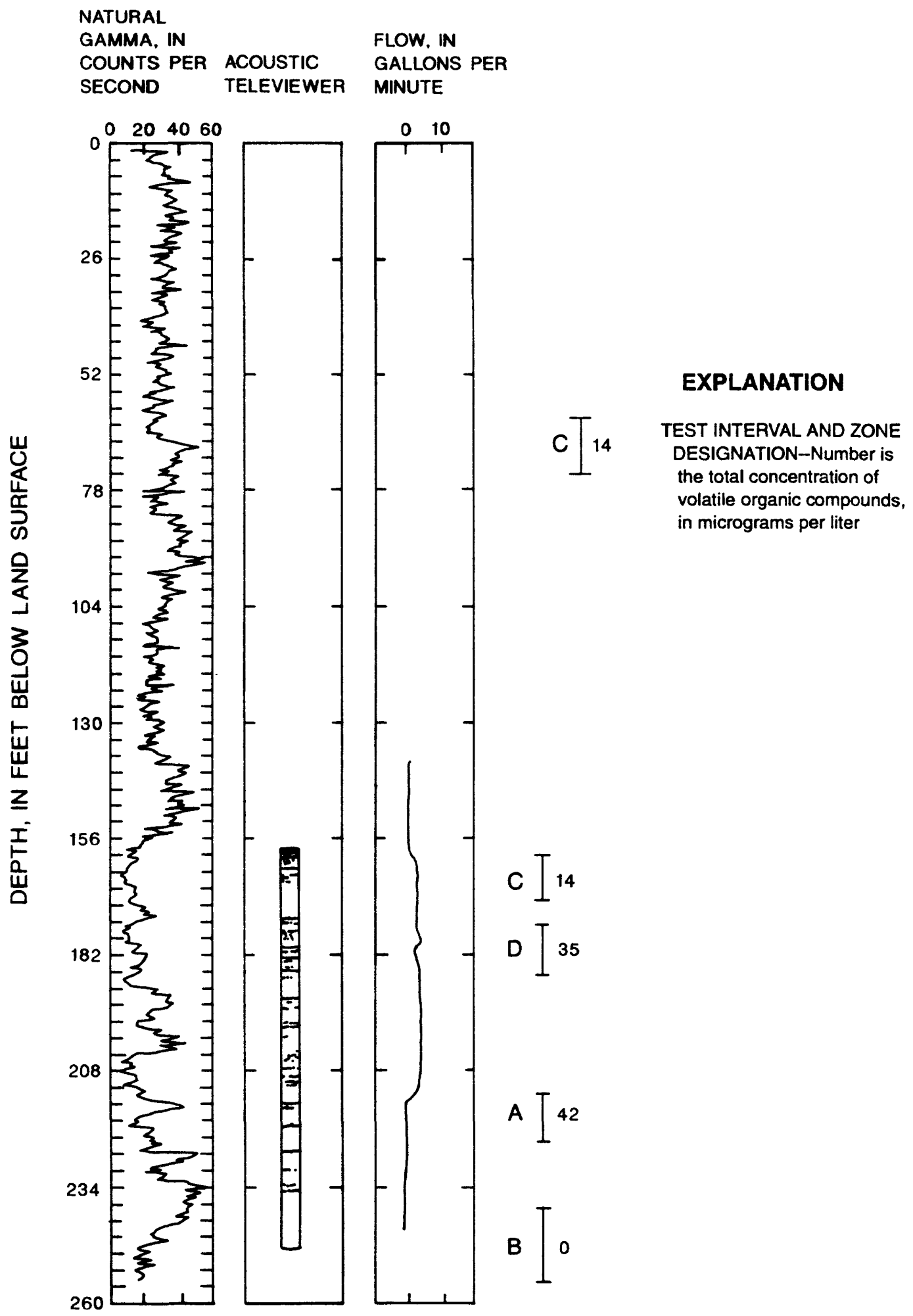

Figure 8. Natural-gamma, acoustic-televiewer, and flowmeter data, and total concentration of volatile organic compounds in the packed intervals for borehole BH3 in the vicinity of the Southeast Rockford Ground-Water Contamination Site. 


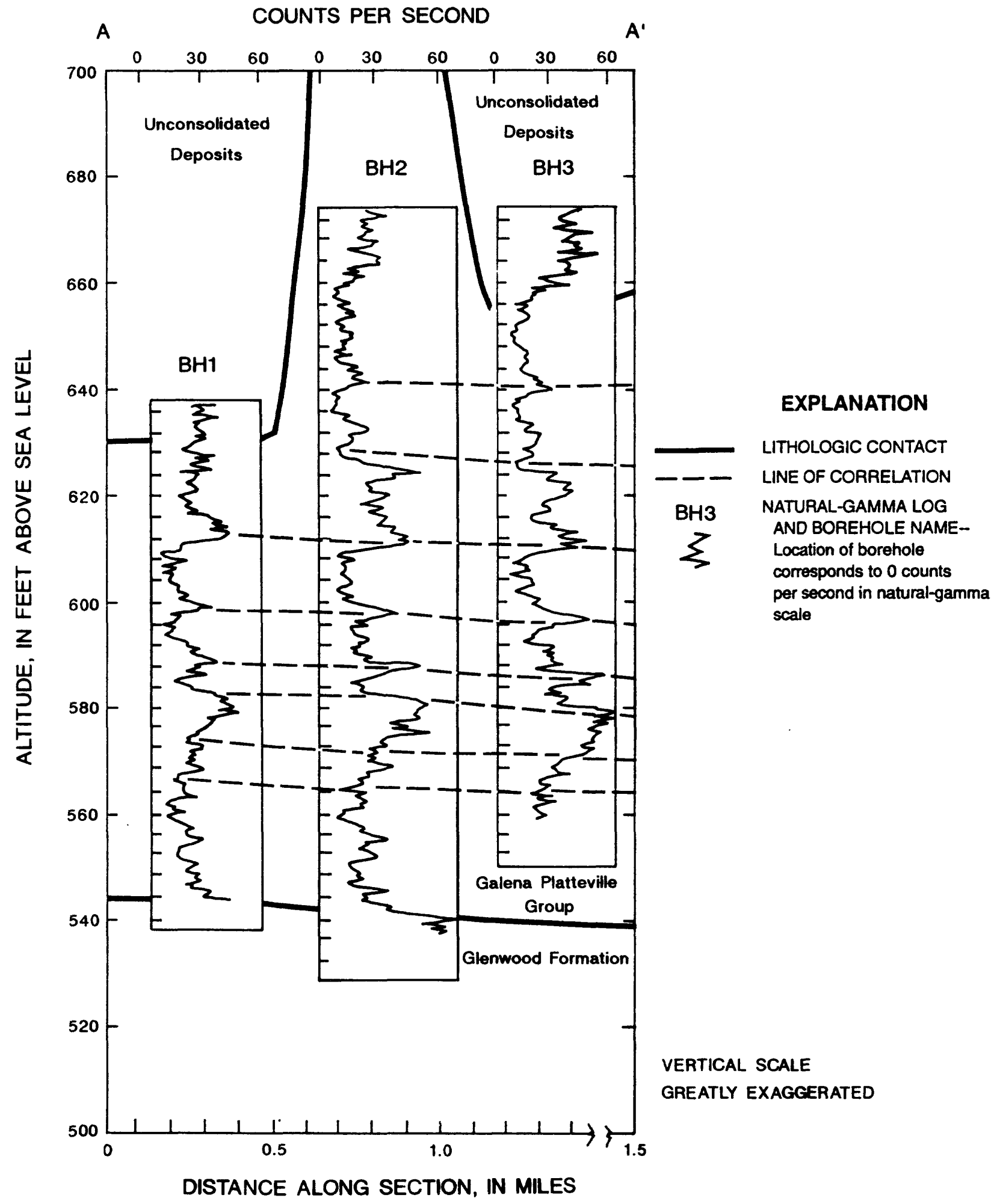

Figure 9. Correlation of natural-gamma data along line of section $A-A^{\prime}$ in the vicinity of the Southeast Rockford Ground-Water Contamination Site. 


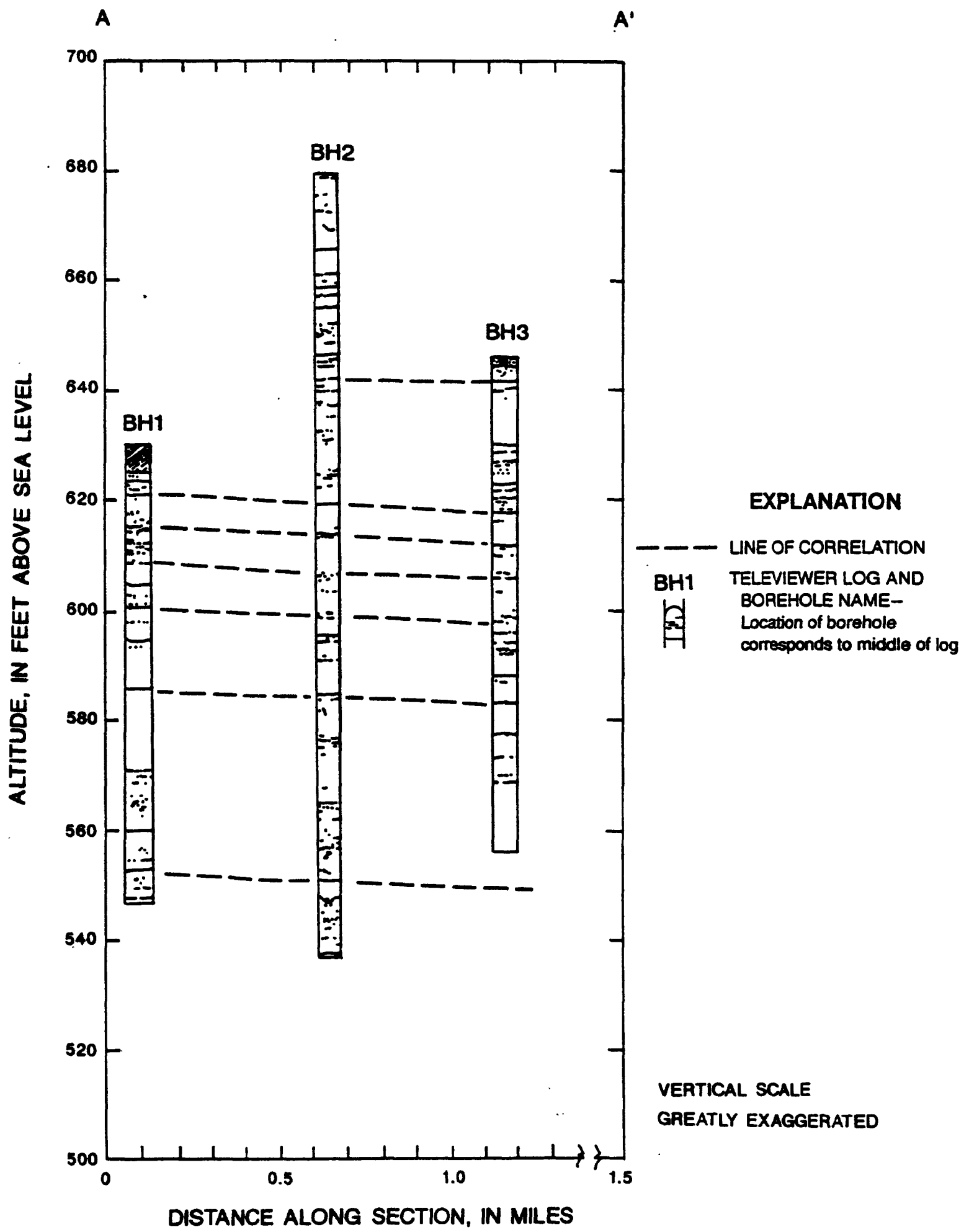

Figure 10. Correlation of acoustic-televiewer data along line of section $A-A^{\prime}$ in the vicinity of the Southeast Rockford Ground-Water Contamination Site. 


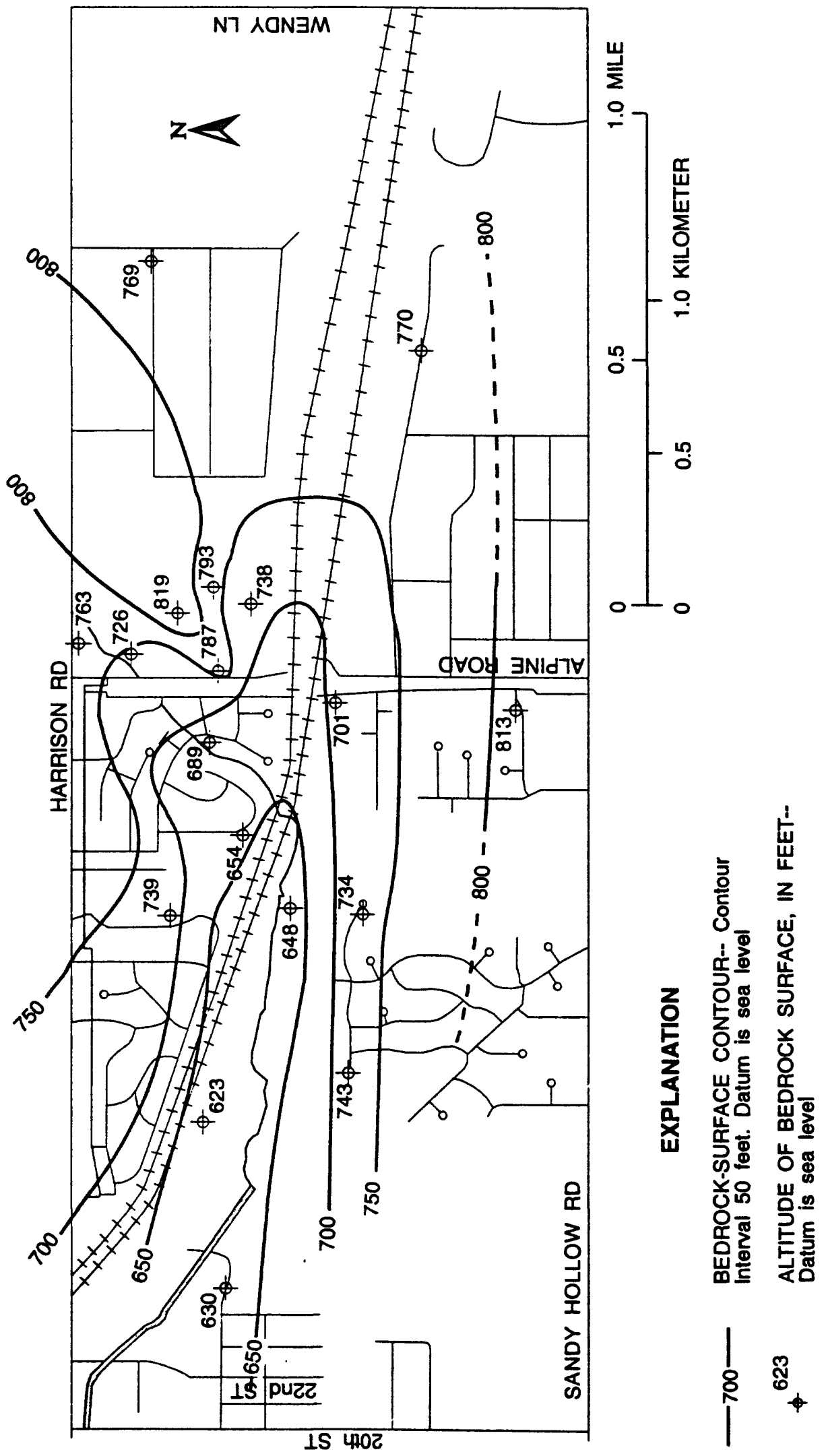

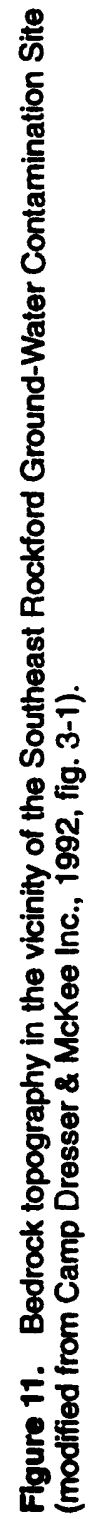




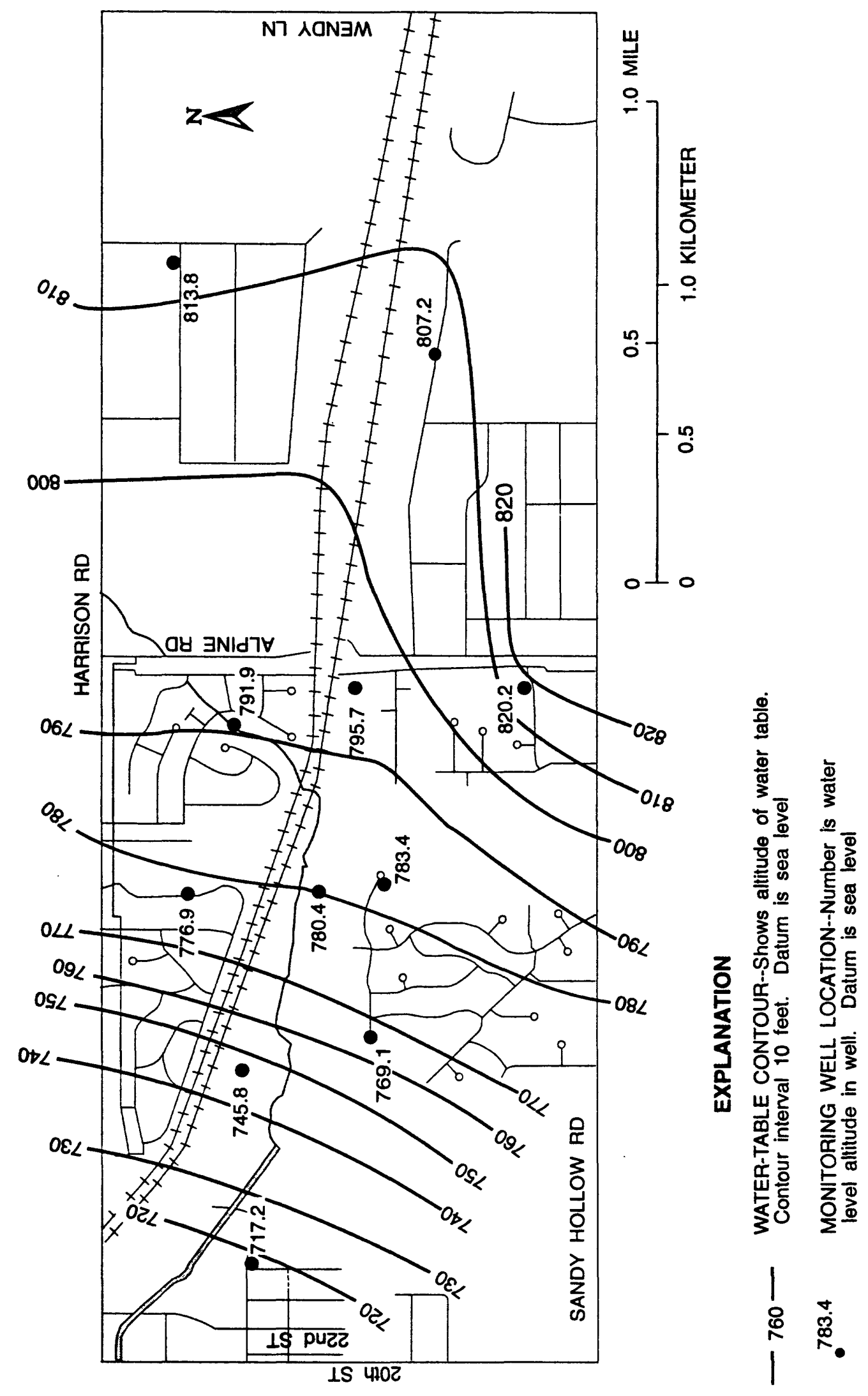

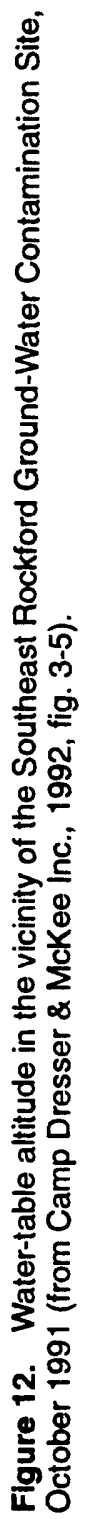


indicate the potential for downward flow in most of the Phase I area (Camp Dresser \& McKee Inc., 1992, p. 3-16). These gradients, in concert with the absence of any laterally extensive confining units in the unconsolidated aquifer and the presence of thick sand layers directly above the dolomite, indicate that the dolomite aquifer is hydraulically well connected to the unconsolidated aquifer in most of the study area.

\section{Dolomite Aquifer}

The dolomite aquifer is a "double-porosity" aquifer. Ground-water flow in the aquifer is primarily through discrete conduits (joints, vugs, fractures, and solution openings) in the rock. However, some flow takes place through the porous matrix, and between the matrix and the discrete conduits. Most of the aquifer storage is in the porous matrix of the dolomite.

The mean horizontal hydraulic conductivity of the dolomite aquifer calculated from slug-test data collected from nine monitoring wells that are open to the aquifer is $2.6 \times 10^{\circ} \mathrm{ft} / \mathrm{d}$ (Camp Dresser \& McKee Inc., 1992, p. 3-17). A transmissivity of $6.5 \times 10^{2} \mathrm{ft}^{2} / \mathrm{d}$ and a horizontal hydraulic conductivity of $6.5 \times 10^{0} \mathrm{ft} / \mathrm{d}$ were calculated from a constant-discharge aquifer test in the dolomite aquifer near Alpine and Harrison Streets (EDI Engineering and Science, 1989, p. 2-1). The fact that these values are all within an order of magnitude indicates that the aquifer is fairly homogeneous where the tests were conducted.

Boreholes $\mathrm{BH} 1, \mathrm{BH} 2$, and $\mathrm{BH} 3$ were pumped at $35.7,39.0$, and $36.0 \mathrm{gal} / \mathrm{min}$, respectively, during the first week of December 1992 for purging and development. After being pumped for 60 minutes, $1.38 \mathrm{ft}$ of drawdown was induced in borehole $\mathrm{BH} 1,9.31 \mathrm{ft}$ of drawdown was induced in borehole $\mathrm{BH} 2$, and $10.95 \mathrm{ft}$ of drawdown was induced in borehole BH3.

The transmissivity of the dolomite aquifer at boreholes $\mathrm{BH} 1, \mathrm{BH} 2$, and $\mathrm{BH} 3$ was estimated to be $6.8 \times 10^{3}, 1.0 \times 10^{3}$, and $7.4 \times 10^{2} \mathrm{ft}^{2} / \mathrm{d}$, respectively, on the basis of an analysis of the specific capacity data obtained during purging (Walton, 1962, p. 12). As applied here, the use of specific capacity as an index of transmissivity assumes the following conditions:

1. Well loss is negligible.

2. The well penetrates the entire saturated thickness of the aquifer.
3. The effective radius of the well has not been affected by well development and is equal to the nominal radius of the well $(0.5 \mathrm{ft})$.

4. The storage coefficient of the aquifer is 0.0001 .

These conditions are likely to be approximated in the aquifer at each of the boreholes, but these tranmissivity values should still be considered rough estimates.

If the transmissivities calculated from the three specific-capacity tests are divided by the thickness of the open interval of the boreholes $(88 \mathrm{ft}$ for $\mathrm{BH} 1,190 \mathrm{ft}$ for $\mathrm{BH} 2,92 \mathrm{ft}$ for $\mathrm{BH} 3$ ), the horizontal hydraulic conductivities for boreholes $\mathrm{BH} 1, \mathrm{BH} 2$, and $\mathrm{BH} 3$ are $7.7 \times 10^{1}, 5.3 \times 10^{0}$ and $8.0 \times 10^{0} \mathrm{ft} / \mathrm{d}$, respectively. The horizontal hydraulic conductivities near the center of the buried-bedrock valley are significantly higher than those on the flanks of the valley, indicating a large number of interconnected fractures in the dolomite at the bedrock valley.

Water-level data indicate that ground water in the dolomite aquifer flows from southeast to northwest across the eastern part of the Phase I area (fig. 13). This direction of flow is similar to that in the unconsolidated aquifer.

Measurements of vertical variations in head within the dolomite aquifer were made in discrete test intervals in boreholes $\mathrm{BH} 1$ and $\mathrm{BH} 2$ (table 2). These test intervals were isolated by use of a packer assembly consisting of two 4-ft-long inflatable neoprene packers separated by $10 \mathrm{ft}$ of stainless-steel screen (fig. 14). The packer assembly was constructed so that groundwater levels could be obtained from the intervals above, below, and within the test interval after the packers were inflated and water levels had equilibrated. The differences in water levels between intervals demonstrate that the packers effectively sealed the test interval from the rest of the borehole.

Water levels from the test intervals indicate the potential for downward flow within the dolomite aquifer, especially at borehole $\mathrm{BH} 2$. Water levels below the test interval in borehole $\mathrm{BH} 2$ were from 16 to $41 \mathrm{ft}$ lower than water levels above the test interval. Water levels below the test interval in borehole BH1 generally were 0.5 to $10 \mathrm{ft}$ lower than water levels above the test interval.

The magnitude of the vertical differences in head within an aquifer are affected by, among other things, the vertical hydraulic conductivity of the aquifer. It can be inferred, therefore, that the vertical hydraulic conductivity of the dolomite aquifer is 


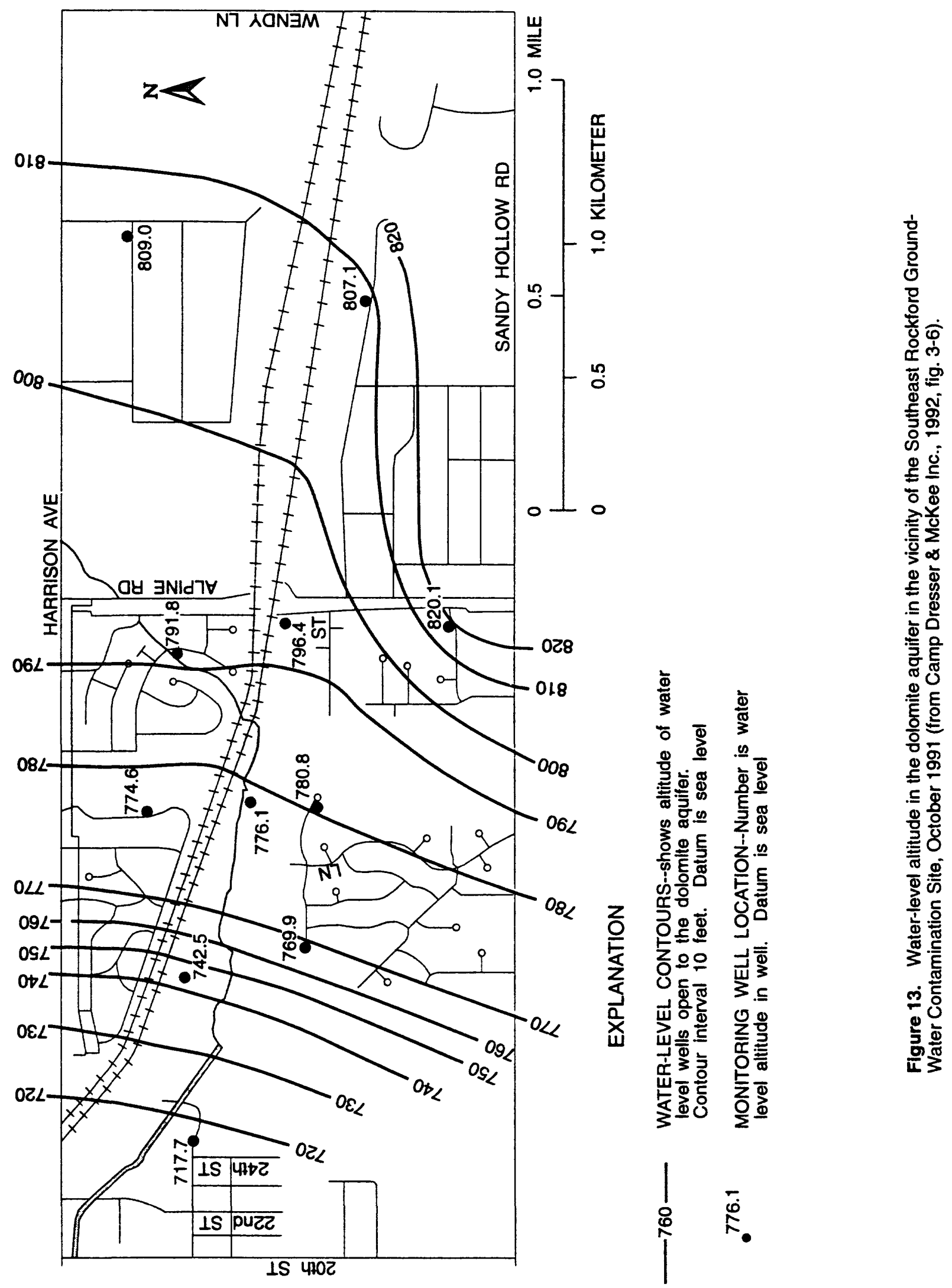




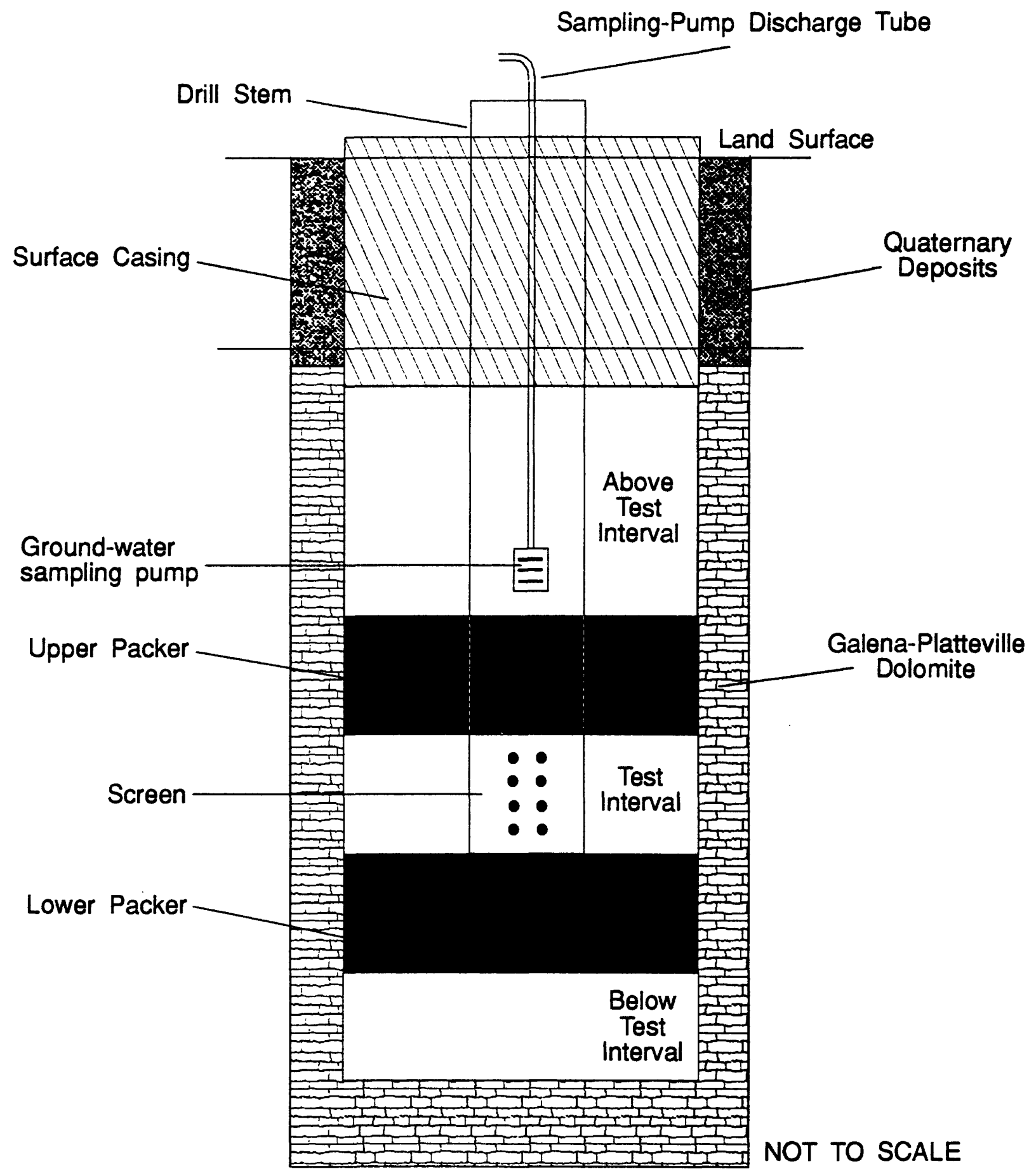

Figure 14. Diagram of the packer assembly and ground-water-sampling pump in a borehole. 
Table 2. Depth to water above, within, and below the test interval under approximately hydrostatic conditions during packer testing in boreholes $\mathrm{BH} 1$ and $\mathrm{BH} 2$, Southeast Rockford Ground-Water Contamination Site [Depth of test interval and depth to water in feet below measurement point; NA, measurement not applicable]

\begin{tabular}{|c|c|c|c|c|c|}
\hline \multirow[b]{2}{*}{$\begin{array}{c}\text { Borehole } \\
\text { name }\end{array}$} & \multirow[b]{2}{*}{ Zone } & \multirow{2}{*}{$\begin{array}{c}\text { Depth } \\
\text { of test } \\
\text { interval } \\
\end{array}$} & \multicolumn{3}{|c|}{ Depth to water } \\
\hline & & & $\begin{array}{l}\text { Above test } \\
\text { interval }\end{array}$ & $\begin{array}{l}\text { in test } \\
\text { interval }\end{array}$ & $\begin{array}{l}\text { Below test } \\
\text { interval }\end{array}$ \\
\hline BH1 & A & $199.2-220.6$ & 47.89 & 50.77 & NA \\
\hline BH1 & B & $181.0-191.0$ & 47.68 & 46.68 & 51.48 \\
\hline BH1 & C & $177.1-187.1$ & 41.16 & 48.96 & 51.87 \\
\hline $\mathrm{BH} 1$ & D & 168.2-178.1 & 47.90 & 48.35 & 52.75 \\
\hline BH1 & $\mathbf{E}$ & $154.0-164.0$ & 48.70 & 49.48 & 50.72 \\
\hline BH1 & F & $148.0-158.0$ & 49.46 & 49.51 & 49.98 \\
\hline $\mathrm{BH} 1$ & $\mathbf{G}$ & $139.0-149.0$ & NA & 51.28 & 49.55 \\
\hline BH2 & A & $233.0-254.2$ & 31.40 & 62.15 & NA \\
\hline BH2 & $\mathrm{C}$ & $198.0-208.0$ & 30.55 & 34.07 & 66.62 \\
\hline $\mathrm{BH} 2$ & B & $188.0-198.0$ & 23.86 & 43.40 & 64.94 \\
\hline $\mathrm{BH} 2$ & D & $128.0-138.0$ & 22.55 & 27.78 & 45.80 \\
\hline $\mathrm{BH} 2$ & $\mathbf{E}$ & $92.0-102.0$ & 22.40 & 23.33 & 42.90 \\
\hline $\mathrm{BH} 2$ & $\mathbf{F}$ & $48.3-58.0$ & NA & 22.73 & 38.48 \\
\hline
\end{tabular}

significantly lower at borehole $\mathrm{BH} 2$ than it is at borehole BH1. Because the vertical hydraulic conductivity of the dolomite aquifer is affected by the degree of verticalfracture interconnection, it also can be inferred that there are more inclined fractures near borehole $\mathrm{BH} 1$ than near borehole $\mathrm{BH} 2$. This is consistent with the analysis of the specific-capacity tests.

In both boreholes, the difference in the water levels above and below the test interval generally increased as the depth of the test interval increased. This increase indicates that the degree of verticalfracture interconnection decreases with depth in the aquifer.

Flowmeter logging was conducted under conditions of natural flow to identify intervals of groundwater flow into or out of boreholes $\mathrm{BH} 1, \mathrm{BH} 2$, and $\mathrm{BH} 3$ to obtain a more detailed understanding of the hydrology of the dolomite aquifer (figs. 6-8, 15). If vertical variations in head are present within the aquifer, vertical flow within the borehole is induced. The rate of vertical flow can be measured throughout the borehole to identify areas of significant changes in the amount of flow into or out of the borehole. The depths where the amount of flow changes are commonly intervals where the horizontal hydraulic conductivity in the aquifer is high. Thus, flowmeter logging can be an effective tool for profiling permeability and flow within the aquifer.

Flowmeter logging was initially attempted with the heat-pulse flowmeter in each borehole. The rate of vertical flow in each of these boreholes, however, was greater than the upper measurement limit ( $2 \mathrm{gal} / \mathrm{min}$ ) of the heat-pulse flowmeter, necessitating the use of an impeller-type flowmeter. Because the impeller flowmeter is designed to measure high flow rates, it is incapable of measuring flow rates less than $2 \mathrm{gal} / \mathrm{min}$ and changes in flow rates of under $1 \mathrm{gal} / \mathrm{min}$. It is possible, therefore, that minor inflow and outflow in the borehole was present but could not be measured.

Flowmeter logging indicates that ground-water flow is vertically downward in all of the boreholes under conditions of natural flow. This finding is consistent with the results of the water-level data collected during packer testing (table 2).

The rate of downward flow in these boreholes was as high as $7.3 \mathrm{gal} / \mathrm{min}$ in $\mathrm{BH} 1,8.0 \mathrm{gal} / \mathrm{min}$ in $\mathrm{BH} 2$, and $4.0 \mathrm{gal} / \mathrm{min}$ in $\mathrm{BH} 3$. These flow rates are high for an aquifer under unstressed conditions and probably are caused by a combination of highly permeable zones in the dolomite and large vertical head gradients.

Comparison of acoustic-televiewer data with the intervals of measured changes in the amount of flow identified on the flowmeter logs indicates that most of the flow in the aquifer is through fractures in the weathered upper part of the dolomite and through subhorizontal fractures interspersed throughout the dolomite (figs. 6-8). This is typical of flow in a fractured-rock aquifer. 


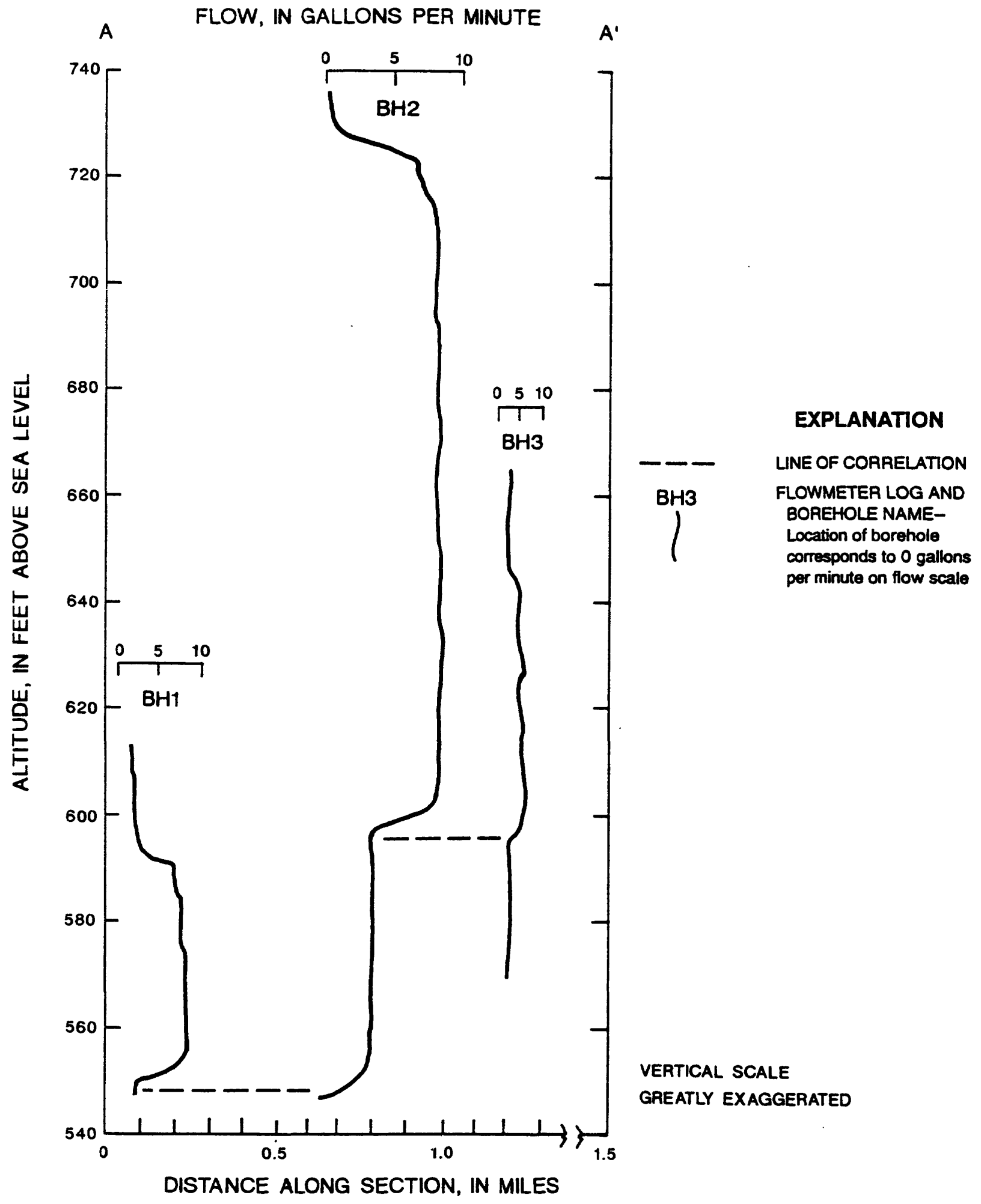

Figure 15. Diagram showing correlation of flowmeter data along line of section $A-A^{\prime}$ in the vicinity of the Southeast Rockford Ground-Water Contamination Site. 
Flowmeter logging in borehole $\mathrm{BH} 1$ showed that water was entering the borehole along the subhorizontal fractures at depths between 140 and $144 \mathrm{ft}$ and 163, 169, and $177 \mathrm{ft}$ (fig. 6). Water flowed out of the borehole through the subhorizontal fracture at a depth of $203 \mathrm{ft}$.

Flowmeter logging in borehole $\mathrm{BH} 2$ showed inflow along one or more subhorizontal fractures at depths between 46 and $58 \mathrm{ft}$ and from a subhorizontal fracture at a depth of $129 \mathrm{ft}$ (fig. 7). Outflow was through the subhorizontal fractures at depths of 191 and $248 \mathrm{ft}$. No inflow or outflow was detected in the rest of the borehole.

Flowmeter logging in borehole BH3 showed inflow at a number of fractures at depths between about 159 and $162 \mathrm{ft}$ and 179 and $184 \mathrm{ft}$ (fig. 8). Outflow was measured at the fracture at a depth of $213 \mathrm{ft}$. No flow was detected between a depth of $213 \mathrm{ft}$ and the bottom of the borehole at a depth of $250.5 \mathrm{ft}$.

Aside from the flow in the upper few feet of the aquifer, where the dolomite is heavily weathered, there is no evidence of any fracture that is transmitting ground water throughout the study area (fig. 15). Flowmeter data indicate that a fracture at an altitude of about $600 \mathrm{ft}$ above sea level may be transmitting water in the area between boreholes $\mathrm{BH} 2$ and $\mathrm{BH} 3$. A subhorizontal fracture at an altitude of about $550 \mathrm{ft}$ above sea level may be transmitting water in the area between boreholes $\mathrm{BH} 1$ and $\mathrm{BH} 2$. It is unknown whether flow occurs through this deeper fracture near borehole BH3.

\section{Sandstone Aquifer}

The sandstone aquifer is the uppermost unit of the Cambrian-Ordovician Aquifer system (Young, 1992, p. A9), one of the principal water-supply aquifers in northern Illinois. This aquifer is the uppermost aquifer to which Rockford municipal well 16 is open. Pumping schedules obtained from the city of Rockford for December 7-22, 1992, show that Rockford municipal well 16 is pumped at a constant rate of $1,000 \mathrm{gal} / \mathrm{min}$ several times a day, usually for 65 to 80 minutes. On most days, the well is not pumped between midnight and 7 a.m.

Ground-water flow in the sandstone aquifer is from east to west beneath the southeast Rockford area (Wehrman and others, 1988, p. 34). The direction of flow between the sandstone aquifer and the overlying aquifers has not been clearly identified but is presumed to be downward in the study area (Wehrman and others, 1988, p. 37).

It is assumed that the argillaceous deposits of the Glenwood Formation do not constitute a semiconfining unit in this area and that the sandstone aquifer is in direct hydraulic connection with the dolomite aquifer. No monitoring wells are open to the sandstone aquifer to support this assumption. However, investigators at a Superfund site about $15 \mathrm{mi}$ south of the study area (Harding-Lawson Associates, 1990) noted the presence of low vertical hydraulic gradients across the Glenwood Formation. Investigators at a Superfund site about $10 \mathrm{mi}$ east of the study area noted that pumping in the sandstone aquifer resulted in significant water-level declines in the dolomite aquifer (P.C. Mills, U.S. Geological Survey, oral commun., 1993). Data from these sites indicates that the Glenwood Formation is not an effective semiconfining unit in the Rockford area.

The absence of a semiconfining unit between the two bedrock aquifers indicates that VOC's, if present near the bottom of the dolomite aquifer, can migrate down into the sandstone aquifer. Pumping of water from the sandstone aquifer at a municipal-supply well could increase the downward migration of water by inducing drawdown in the sandstone aquifer. This drawdown would result in an increase in the head difference between the two aquifers, increasing the amount of flow from the dolomite into the sandstone. Once VOC's enter the sandstone aquifer, transport to a water-supply well is possible.

Comparison of ground-water levels in borehole BH3 with pumping schedules in Rockford municipal well 16 over a 17-day period in December 1992 gave no clear indication that the effects of pumping in the Cambrian-Ordovician aquifer system extended to the lower part of the dolomite aquifer in this part of the study area (fig. 16). Although ground-water levels in the dolomite aquifer at borehole BH3 often declined during periods of pumping and rose during periods when pumping ceased in the sandstone aquifer, the total change in water level during the entire period of monitoring was $0.58 \mathrm{ft}$. Ground-water level changes of this magnitude can result from changes in barometric pressures or background water-level fluctuations.

A detailed analysis of water-level change and pumping demonstrates that ground-water levels were essentially unchanged during periods of unusually heavy pumping on December 8 and 17 and during a period of decreasing pumping from December 11-13. 


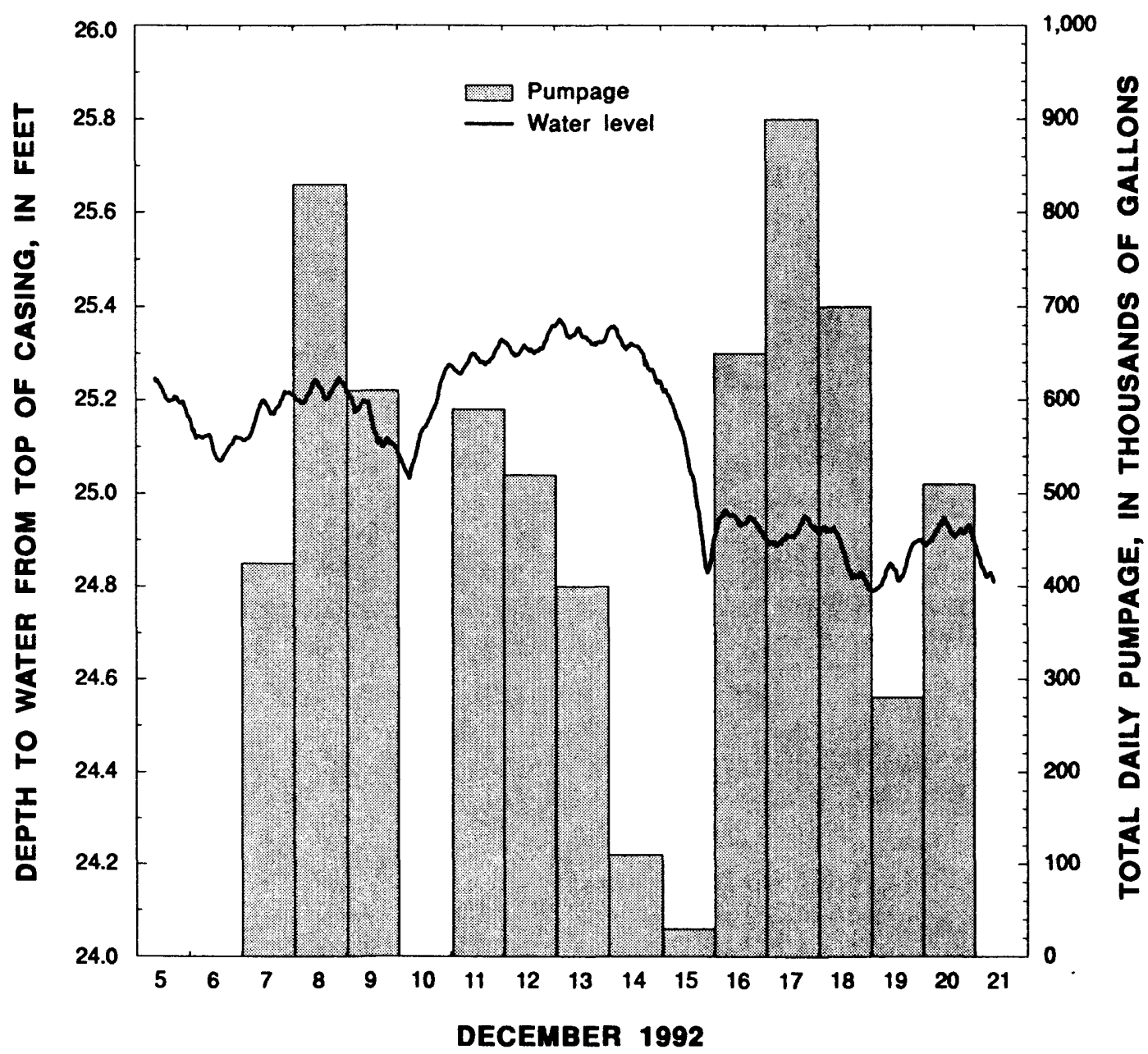

Figure 16. Water level in borehole $\mathrm{BH} 3$ and total daily pumpage from Rockford municipal well 16, Rockford, III., December 5-21, 1992.

Water levels in borehole BH3 actually declined on December 10 when there was no pumping and on December 15 when pumping was negligible. Water levels rose during a period of moderate pumping on December 9.

The apparent absence of pumping stresses in the dolomite aquifer at borehole BH3 indicates that VOC's more than $30 \mathrm{ft}$ above the top of the Glenwood Formation and farther than $2,750 \mathrm{ft}$ from municipal well 16 are not migrating under the influence of pumping in the sandstone aquifer. This area includes most of the southern plume. However, the effects of pumping in the municipal well are likely to be greater in the sandstone aquifer than in the dolomite aquifer.
The results of the water-level monitoring should not be considered conclusive. Further monitoring would be required for a complete hydrologic description under a variety of pumping conditions.

\section{GROUND-WATER QUALITY}

Ground-water quality in the unconsolidated deposits and the upper part of the dolomite aquifer has been characterized in some detail by previous investigators. This investigation was designed to focus on water quality in the deeper parts of the dolomite aquifer. Ground-water quality in the underlying sandstone aquifer may need to be characterized. 


\section{Sample Collection and Analysis}

Water samples were collected from packed-off zones in boreholes $\mathrm{BH} 1, \mathrm{BH} 2$, and $\mathrm{BH} 3$. The packers were used to isolate the top and bottom of each borehole, all zones of measurable flow identified by the flowmeter logging, and at least two zones where no measurable flow was identified by the flowmeter logging. All of the samples were collected and analyzed for concentrations of VOC's according to Quality Assurance and Quality Control (QAQC) guidelines outlined in the approved Quality Assurance Project Plan for this effort (Karen Vendl, U.S. Environmental Protection Agency, written commun., 1992).

Each of the boreholes was purged of at least $4,200 \mathrm{gal}$ of water with a high-capacity submersible pump before sample collection. Purging was done to develop the borehole, to remove water that had been affected by the drilling process, and to remove water that had been emplaced by vertical flow within the borehole. It is important to recognize, however, that because of the high rate of vertical flow within the boreholes, water collected from zones where water was flowing from the borehole into the aquifer is probably not completely representative of the actual water quality at that depth. It is assumed that the results of the water-quality sampling from the packed intervals have not been significantly affected by vertical flow within the borehole.

Low-flow ground-water sampling pumps were used to collect water samples (fig. 14). In those zones that could be pumped continuously, a minimum of two well volumes (volume of water in the standpipe above the packer plus the volume of water in the borehole within the test interval) were purged with the sampling pumps before sample collection (table 3 ). In those zones that could not sustain continuous pumping, a minimum of 1.5 standpipe volumes were purged prior to sample collection. Water-quality samples collected from those zones that were purged of less than $\mathbf{4 0} \mathrm{gal}$ probably represent a combination of water derived from inflow higher in the borehole (which was flowing down through the borehole and was trapped when the packers were inflated) and water derived from the aquifer within the packed interval (which flowed into the test interval during purging).
Table 3. Volume of water purged from test intervals before sample collection in boreholes $\mathrm{BH} 1, \mathrm{BH} 2$, and $\mathrm{BH} 3$, Southeast Rockford Ground-Water Contamination Site

[Depth of test interval in feet below measurement point; volume of water purged is in gallons]

\begin{tabular}{|c|c|c|c|}
\hline $\begin{array}{l}\text { Borehole } \\
\text { name }\end{array}$ & Zone & $\begin{array}{c}\text { Depth of test } \\
\text { interval }\end{array}$ & $\begin{array}{c}\text { Volume of } \\
\text { water purged }\end{array}$ \\
\hline BHI & A & $199.2-220.6$ & 155 \\
\hline BH1 & B & $181.0-191.0$ & 30 \\
\hline BH1 & C & $177.1-187.1$ & 130 \\
\hline BH1 & D & 168.2-178.1 & 140 \\
\hline BH1 & E & $154.0-164.0$ & 100 \\
\hline BH1 & $\mathrm{F}$ & $148.0-158.0$ & 100 \\
\hline BH1 & $\mathbf{G}$ & $139.0-149.0$ & 105 \\
\hline BH2 & A & $233.0-254.2$ & 120 \\
\hline BH2 & C & $198.0-208.0$ & 51 \\
\hline BH2 & $\mathbf{B}$ & $188.0-198.0$ & 120 \\
\hline BH2 & D & $128.0-138.0$ & 95 \\
\hline BH2 & $\mathbf{E}$ & $92.0-102.0$ & 110 \\
\hline BH2 & $\mathbf{F}$ & $48.3-58.0$ & 240 \\
\hline BH3 & B & $233.0-250.0$ & 135 \\
\hline BH3 & A & $213.0-223.0$ & 120 \\
\hline BH3 & D & $177.0-187.0$ & 120 \\
\hline BH3 & $\mathrm{C}$ & $159.0-169.0$ & 120 \\
\hline
\end{tabular}

Samples were analyzed by the USEPA lab using the gas chromatography and mass spectrometry method. Laboratory-reported concentrations are rounded down to the nearest microgram per liter in this report. No formal QAQC analysis of the data was attempted by the lab. An analysis of the QAQC procedures by the USGS indicates that the quality of the lab results were acceptable, that field and laboratory contamination of the samples was minimal, and that field decontamination procedures were adequate to prevent crosscontamination. Any VOC detection attributed to field or laboratory contamination is not included in this report. A more detailed analysis of the analytical results may be obtained from the USGS.

Water-quality sampling from the packed intervals was done to obtain detailed data on the types, concentrations, and vertical distribution of VOC's in the dolomite aquifer. This data was used to define the probable pathways by which VOC's are migrating within the aquifer and to identify zones of chemical interest in the aquifer. Identification of the zones of chemical interest enabled the optimal depth of the well screens to be determined when the monitoring wells were installed in the boreholes. Proper placement of the well screens ensured that as much useful information as possible was collected when the monitoring well was sampled. 


\section{Results of Analyses}

The only VOC's detected in the boreholes were chlorinated ethenes and chlorinated ethanes (table 4). The total concentration of VOC's exceeded $2,000 \mu \mathrm{g} / \mathrm{L}$ in at least one sample each from boreholes $\mathrm{BH} 1$ and $\mathrm{BH} 2$. The total concentration of VOC's exceeded $40 \mu \mathrm{g} / \mathrm{L}$ in one sample from borehole $\mathrm{BH} 3$.

The presence of VOC's at borehole BH3, an area of the aquifer where VOC's were previously thought to be absent (figs. 2-4), indicates that the northern plume extends farther south than was previously recognized. The absence of VOC's in samples collected from well MW107C, the nearest upgradient monitoring well in the dolomite aquifer, indicated that the northern plume was much narrower than the data from borehole $\mathrm{BH} 3$ show it to be. Extrapolation of the VOC data from borehole $\mathrm{BH} 3$ indicates that the northern and southern plumes may merge somewhere to the southwest of borehole BH3.

The detection of VOC concentrations in excess of $30 \mu \mathrm{g} / \mathrm{L}$ at borehole $\mathrm{BH} 3$ demonstrates the advantages of intensive characterization of flow and ground-water quality in fractured-rock aquifers. Though by no means the only explanations, it is possible that VOC's were not detected in samples from well MW107C because the well is screened in a part of the dolomite where groundwater flow is insignificant or the VOC plume is above or below the depth of the well screen. A more intensive study of flow and ground-water quality in the aquifer at well MW107C could have helped in selecting the depth of the well screen to define the nature and extent of the northern plume.

Results of the water-quality sampling indicate that, at these boreholes, VOC's are present throughout the entire thickness of dolomite aquifer where flow is measurable (figs. 6-8). Zone $\mathrm{B}$ in borehole $\mathrm{BH}$, below the point of outflow (fig. 8), is the only zone in these boreholes where no VOC's deemed representative of water quality in the dolomite aquifer were detected. This finding indicates that the VOC's are being transported primarily by advective flow through the fractures in the dolomite.

The types and relative concentrations of VOC's in boreholes $\mathrm{BH} 1$ and $\mathrm{BH} 2$ are similar but differ significantly from those in borehole BH3. Neither the types nor relative concentrations of VOC's change significantly with depth in these boreholes.

In boreholes $\mathrm{BH} 1$ and $\mathrm{BH} 2$, trichloroethane (TCA) is the VOC present at the highest concentration in every zone (table 4). In borehole BH3, TCA either is absent or is present at the lowest concentrations of any VOC detected. Cis-1,2-dichloroethene (C1,2-DCE) is present at the second-highest concentration in every zone of boreholes $\mathrm{BH} 1$ and $\mathrm{BH} 2$, except zone $\mathrm{E}$ in borehole $\mathrm{BH}$. In borehole $\mathrm{BH}, \mathrm{C1}, 2-\mathrm{DCE}$ is the VOC present at the highest concentrations in every zone. Trichloroethene (TCE) is present at the thirdhighest concentration in every zone of boreholes $\mathrm{BH} 1$ and $\mathrm{BH} 2$ except zone $\mathrm{C}$ of borehole $\mathrm{BH} 1$, where it is absent, and zone $\mathrm{E}$ of borehole $\mathrm{BH} 2$, where it is present at the second-highest concentration. No TCE was detected in borehole $\mathrm{BH}$. Carbon tetrachloride, tetrachloroethene, 1,1-dichloroethene, and 1,1-dichloroethane also were detected in high concentrations in boreholes $\mathrm{BH} 1$ and $\mathrm{BH} 2$. Of these four compounds, only 1,1-dichloroethane was detected in borehole $\mathrm{BH} 3$.

Both C1,2-DCE and 1,1-dichloroethane can be formed from the reductive dehalogenation of trichlorinated ethenes and ethanes, which can be formed from the reductive dehalogenation of tetrachlorinated ethenes and ethanes (Bouwer and McCarty, 1983, p. 1286; Vogel and McCarty, 1985, p. 1080). The presence of high concentrations of degradation products in boreholes $\mathrm{BH} 1, \mathrm{BH} 2$, and $\mathrm{BH} 3$ indicates that chlorinated ethenes and ethanes are being biodegraded in the study area.

The types and relative concentrations of VOC's detected at boreholes $\mathrm{BH} 1$ and $\mathrm{BH} 2$ during the current investigation are similar to those detected from monitoring wells in these areas during previous studies (Camp Dresser \& McKee Inc., 1992, p. 4-27, 4-28). This consistency of results tends to confirm the accuracy of the water-quality analysis done for this investigation.

In borehole $\mathrm{BH} 1$, the total concentration of VOC's in the dolomite aquifer increases consistently between $140 \mathrm{ft}$ and the fractures at 163 and $168 \mathrm{ft}$, which are supplying most of the water from zones $D$ and $E$ (fig. 6). Concentrations decrease significantly in zone $\mathrm{C}$, which obtains most of its water from the fracture at $177 \mathrm{ft}$, before increasing again in zones A and B. It is possible that the high VOC concentrations in zone $B$ represent water from the upper zones that is trapped in this nontransmissive area. It also is possible that the VOC concentrations in zone $A$ are primarily representative of water from the upper zones that flowed into the aquifer through the fracture at $203 \mathrm{ft}$. The short period of time that transpired between drilling, purging, and sampling in this borehole-and the high transmissivity of the fracture, inferred from the significant amount of 
Table 4. Results of water-quality sampling from test intervals in boreholes $\mathrm{BH} 1, \mathrm{BH} 2$, and $\mathrm{BH}$, Southeast Rockford Ground-Water Contamination Site

[Measurement point altitude is in feet above sea level; depth of test interval in feet below measurement point; volatile organic compound concentration in micrograms per liter, 1,1-DCE, 1,1-dichloroethene; 1,1-DCA, 1,1-dichloroethane; C1, 2-DCE, cis-1, 2-dichloroethene; 1,1,1-TCA, 1,-1,1-trichloroethane; CTC, carbon tetrachloride; TCE, trichloroethene; PCE, tetrachloroethene; Dup., duplicate sample]

\begin{tabular}{|c|c|c|c|c|}
\hline $\begin{array}{l}\text { Borehole } \\
\text { name }\end{array}$ & Zone & $\begin{array}{c}\text { Weasurement- } \\
\text { point } \\
\text { altitude }\end{array}$ & $\begin{array}{c}\text { Depth of } \\
\text { test } \\
\text { interval }\end{array}$ & $\begin{array}{l}\text { Volatile organic compound } \\
\text { detected/concentration }\end{array}$ \\
\hline BH1 & $\mathbf{A}$ & 790.86 & 199.2-220.6 & $\begin{array}{l}\text { 1,1,1-TCA/980; C1,2-DCE/380; TCE/250; } \\
\text { 1,1-DCA/210; CTC/170; 1,1-DCE/100; PCE/95 }\end{array}$ \\
\hline BH1 & A Dup. & 790.86 & $199.2-220.6$ & $\begin{array}{l}\text { 1,1,1-TCA/960; C1,2-DCE/390; TCE/260; } \\
\text { 1,1-DCA/200; CTC/180; 1,1-DCE/93; PCE/89 }\end{array}$ \\
\hline BH1 & B & 790.86 & $181.0-191.0$ & $\begin{array}{l}\text { 1,1,1-TCA/970; C1,2-DCE/380; TCE/260; } \\
\text { 1,1-DCA/210; CTC/170; 1,1-DCE/92; PCE/91 }\end{array}$ \\
\hline BH1 & B Dup. & 790.86 & $181.0-191.0$ & $\begin{array}{l}\text { 1,1,1-TCA } / 1,100 ; \mathrm{Cl}, 2-\mathrm{DCE} / 420 ; \mathrm{TCE} / 280 \\
\text { 1,1-DCA/230; CTC/200; 1,1-DCE/100; PCE } / 100\end{array}$ \\
\hline BHI & C & 790.86 & 177.1-187.1 & 1,1,1-TCA/130; C1,2-DCE/47; 1,1-DCA/31 \\
\hline BH1 & C Dup. & 790.86 & $177.1-187.1$ & 1,1,1-TCA/130; C1,2-DCE/38; 1,1-DCA/35 \\
\hline BH1 & D & 790.86 & $168.2-178.1$ & $\begin{array}{l}\text { 1,1,1-TCA } / 1,300 ; \mathrm{C} 1,2-\mathrm{DCE} / 330 ; \mathrm{TCE} / 320 ; \\
\text { CTC/240;1,1-DCA/230; PCE } / 150 ; 1,1-\mathrm{DCE} / 120\end{array}$ \\
\hline BH1 & D Dup. & 790.86 & 168.2-178.1 & $\begin{array}{l}\text { 1,1,1-TCA } / 1,300 ; \mathrm{TCE} / 330 ; \mathrm{C} 1,2-\mathrm{DCE} / 310 ; \\
\mathrm{CTC} / 250 ; 1,1-\mathrm{DCA} / 230 ; \mathrm{PCE} / 150 ; 1,1-\mathrm{DCE} / 110\end{array}$ \\
\hline BHI & $\mathbf{E}$ & 790.86 & $154.0-164.0$ & $\begin{array}{l}\text { 1,1,1-TCA } / 1,200 ; \mathrm{C} 1,2-\mathrm{DCE} / 420 ; \mathrm{TCE} / 300 ; \\
\text { CTC/220; } 1,1-\mathrm{DCA} / 220 ; 1,1-\mathrm{DCE} / 130 ; \mathrm{PCE} / 120\end{array}$ \\
\hline BHI & E Dup. & 790.86 & $154.0-164.0$ & $\begin{array}{l}\text { 1,1,1-TCA } / 1,100 ; \mathrm{C} 1,2-\mathrm{DCE} / 400 ; \mathrm{TCE} / 290 \\
\text { CTC/220;1,1-DCA/210; } 1,1-\mathrm{DCE} / 110 ; \mathrm{PCE} / 110\end{array}$ \\
\hline BH1 & $\mathbf{F}$ & 790.86 & $148.0-158.0$ & $\begin{array}{l}\text { 1,1,1-TCA } / 1,100 ; \mathrm{Cl}, 2-\mathrm{DCE} / 370 ; \mathrm{TCE} / 280 ; \\
\text { CTC/200;1,1-DCA/200; } 1,1-\mathrm{DCE} / 110 ; \mathrm{PCE} / 110\end{array}$ \\
\hline BH1 & $\mathbf{G}$ & 790.86 & $139.0-149.0$ & $\begin{array}{l}\text { 1,1,1-TCA/850; C1,2-DCE/250; TCE/230; } \\
\text { 1,1-DCA/170; CTC/160; PCE/90; 1,1-DCE/48 }\end{array}$ \\
\hline BH2 & $\mathbf{A}$ & 790.55 & $233.0-254.2$ & $\begin{array}{l}\text { 1,1,1-TCA/170; C1,2-DCE/79; TCE/69; PCE/47; } \\
\text { 1,1-DCA/27; 1,1-DCE/22 }\end{array}$ \\
\hline BH2 & C & 790.55 & $198.0-208.0$ & $\begin{array}{l}\text { 1,1,1-TCA/1,200; C1,2-DCE/610; TCE/330; } \\
\text { 1,1-DCA/220; CTC/210; PCE/160; } 1,1-\mathrm{DCE} / 110\end{array}$ \\
\hline BH2 & $\mathbf{B}$ & 790.55 & $188.0-198.0$ & $\begin{array}{l}\text { 1,1,1-TCA/600; C1,2-DCE/270; TCE/170; } \\
\text { 1,1-DCA/160; CTC/100; PCE/89; 1,1-DCE/57 }\end{array}$ \\
\hline BH2 & $\mathbf{D}$ & 790.55 & $128.0-138.0$ & $\begin{array}{l}\text { 1,1,1-TCA/690; C1,2-DCE/200; TCE/200; } \\
\text { 1,1-DCA/140; CTC/120; PCE/100; 1,1-DCE/52 }\end{array}$ \\
\hline BH2 & $\mathbf{E}$ & 790.55 & $92.0-102.0$ & $\begin{array}{l}\text { 1,1,1-TCA } / 1,300 ; \mathrm{TCE} / 470 ; \mathrm{Cl}, 2-\mathrm{DCE} / 230 ; \\
\text { CTC/230; PCE/190; } 1,1-\mathrm{DCE} / 190 ; 1,1-\mathrm{DCA} / 170\end{array}$ \\
\hline BH2 & $\mathbf{F}$ & 790.55 & 48.3- 58.0 & $\begin{array}{l}\text { 1,1,1-TCA } / 1,700 ; \mathrm{Cl}, 2-\mathrm{DCE} / 710 ; \mathrm{TCE} / 480 ; \\
\text { CTC/300; 1,1-DCA/290; PCE/240; } 1,1-\mathrm{DCE} / 150\end{array}$ \\
\hline BH3 & B & 810 & $233.0-250$ & None \\
\hline BH3 & $\mathbf{A}$ & 810 & $213.0-223.0$ & $\mathrm{Cl} 1,2-\mathrm{DCE} / 25 ; 1,1-\mathrm{DCA} / 13 ; 1,2-\mathrm{DCA} / 2 ; 1,1,1-\mathrm{TCA} / 2$ \\
\hline BH3 & D & 810 & $177.0-187.0$ & C1,2-DCE/21; 1,1-DCA/11;1,1,1-TCA/3 \\
\hline BH3 & C & 810 & $159.0-169.0$ & $\mathrm{Cl}, 2-\mathrm{DCE} / 8 ; 1,1-\mathrm{DCA} / 5$ \\
\hline BH3 & C Dup. & 810 & $159.0-169.0$ & Cl,2-DCE/9; 1,1-DCA/5 \\
\hline
\end{tabular}


natural flow in the aquifer at this point-indicate that the sample from zone A is fairly representative of the water quality in the aquifer at that depth.

In borehole BH2, the total concentration of VOC's decreases consistently from the maximum concentration at the top of the borehole to the fractures at about $192 \mathrm{ft}$ that supply most of the water from zone B (fig. 7). A second zone of high VOC's is associated with the nontransmissive part of the aquifer at zone C. A second zone of low concentrations is present at the base of the dolomite. If the results from zone $\mathrm{C}$ are excluded, the total concentration of VOC's in borehole $\mathrm{BH} 2$ decreases consistently with depth.

In borehole $\mathrm{BH} 3$, the total concentration of VOC's increases consistently from the top of the borehole to the fracture at $213 \mathrm{ft}$ (fig. 8). The only VOC's detected below $213 \mathrm{ft}$ are considered by the authors to represent field or laboratory contamination.

\section{SUMMARY AND CONCLUSIONS}

A geohydrologic investigation at the Southeast Rockford Ground-Water Contamination Site in Rockford, Ill., was completed in the fall of 1992. The investigation was conducted using data from three boreholes open to the entire thickness of the uppermost bedrock aquifer at the site and was designed to determine the hydraulic properties of that aquifer and to identify the concentration and distribution of volatile organic compounds in the vicinity of the site.

The bedrock geologic units of concern to this investigation are the St. Peter Sandstone and Glenwood Formations and the dolomites of the Platteville and Galena Groups. The bedrock is unconformably overlain by Quaternary sands, silts, and gravels. Naturalgamma data from three boreholes indicate that the beds are nearly horizontal and can be correlated throughout the study area. Acoustic-televiewer data show several large subhorizontal fractures in the dolomite that also can be correlated throughout the study area. Many of the fractures appear to be stratigraphically controlled.

The geologic units are divided into three aquifers: the unconsolidated, dolomite, and sandstone aquifers. The dolomite aquifer is in direct hydraulic connection with the unconsolidated aquifer and the sandstone aquifers.

Water-level measurements indicate that the vertical hydraulic conductivity of the dolomite aquifer is significantly higher near the buried bedrock valley beneath the center of the study area than at the bedrock ridges. Vertical head gradients increase with depth in the dolomite aquifer, indicating that the degree of vertical fracture interconnection in the dolomite decreases with depth.

Comparison of acoustic-televiewer and flowmeter data indicates that most of the flow in the dolomite aquifer is through subhorizontal fractures. Aside from the concentration of flow in the upper few feet of the aquifer, where the dolomite is more heavily weathered, a transmissive fracture was identified in the area between boreholes $\mathrm{BH} 2$ and $\mathrm{BH} 3$. A different transmissive fracture was identified between borehole $\mathrm{BH} 1$ and $\mathrm{BH} 2$.

Comparison of ground-water levels with municipal-well pumping periods indicates that the effects of pumping in the sandstone aquifer do not extend to the lower part of the dolomite aquifer approximately 2,750 ft from the pumped well. This suggests that pumping in the municipal well in not promoting the migration of volatile organic compounds (VOC's) from the dolomite aquifer to the underlying aquifer in that part of the study area where data were collected for this investigation.

VOC's, primarily chlorinated ethenes and chlorinated ethanes, were detected in each of the boreholes tested. The total concentration of VOC's exceeded $2,000 \mu \mathrm{g} / \mathrm{L}$ in several samples. The detection of VOC's in an area of the aquifer where they were thought to be absent indicates that the northern plume extends farther south than was previously recognized. This finding indicates that the northern and southern VOC plumes merge within the boundaries of the study area. The VOC's are present over the entire thickness of dolomite aquifer where flow is measurable. Neither types nor relative concentrations of VOC's change significantly with depth.

\section{REFERENCES CITED}

Bouwer, E.J., and McCarty, P.L., 1983, Transformations of 1- and 2-carbon halogenated aliphatic organic compounds under methanogenic conditions: Applied and Environmental Microbiology, v. 45, no. 4, p. 1286-1294.

Camp Dresser \& McKee Inc., 1990, Southeast Rockford operable unit remedial investigation technical memorandum: Report to the Illinois Environmental Protection Agency, Springfield, Ill., 90 p. 
1992, Technical memorandum for Phase I field activities--Southeast Rockford groundwater contamination project: Report to the Illinois Environmental Protection Agency, Springfield, Ill., 132 p.

EDI Engineering and Science, 1989, Results of hydrogeologic evaluation for Sundstrand Corporation, Rockford, Illinois: Report to the Illinois Environmental Protection Agency, Bureau of Land, Springfield, Ill., $10 \mathrm{p}$.

Foote, G.R., 1982, Fracture analysis in northeastern Illinois and northern Indiana: University of Illinois at Urbana-Champaign, unpublished Master's thesis, $193 \mathrm{p}$.

Harding-Lawson Associates, 1990, Supplemental technical investigation, ACME Solvents site, Winnebago County, Illinois: Report to the U.S. Environmental Protection Agency, Chicago, Ill., 456 p.

Vogel, T.M., and McCarty, P.L., 1985, Biotransformation of tetrachloroethylene to trichloroethylene, dichloroethylene, vinyl chloride, and carbon dioxide under methanogenic conditions: Applied and Environmental Microbiology, v. 49, no. 5, p. 1080-1083.
Walton, W.C., 1962, Selected analytical methods for well and aquifer evaluation: Illinois State Water Survey Bulletin 49, 81 p.

Wehrman, H.A., Holm, T.R., LeSeur, L.P., Curtiss, C.D., Stecyk, A.N., and Berg, R.C., 1988, A regional ground-water quality characterization of the Rockford area, Winnebago County, Illinois: Hazardous Waste Research and Information Center Report HWRIC RR-027, Savoy, Ill., 114 p.

Willman, H.B., Atherton, E.R., Buschbach, T.C., Collinson, C.C., Frye, J.C., Hopkins, M.E., Lineback, J.A., and Simon, J.A., 1975, Handbook of Illinois stratigraphy: Illinois State Geological Survey Bulletin 95, $261 \mathrm{p}$.

Willman, H.B., and Kolata, D.R., 1978, The Platteville and Galena Groups in northern Illinois: Illinois State Geological Survey Circular 502, 76 p.

Young, H.L., 1992, Summary of ground-water hydrology of the Cambrian-Ordovician aquifer system in the northern Midwest, United States: U.S. Geological Survey Professional Paper 1405-A, 55 p. 